\title{
AVALIAÇÃO DA RESISTÊNCIA À FRATURA DE PRÓTESES FIXAS PROVISÓRIAS IMPLANTO-SUPORTADAS VARIANDO O COMPRIMENTO DO CANTILEVER E O TIPO DE FIBRA: FIBRAS DE VIDRO E FIBRAS DE POLI(ARAMIDA)
}

Dissertação apresentada à Faculdade de Odontologia de Bauru da Universidade de São Paulo, como parte dos requisitos para a obtenção do título de Mestre em Odontologia - Área de Reabilitação Oral. 


\section{AVALIAÇÃO DA RESISTÊNCIA À FRATURA DE PRÓTESES FIXAS PROVISÓRIAS IMPLANTO-SUPORTADAS VARIANDO O COMPRIMENTO DO CANTILEVER E O TIPO DE FIBRA: FIBRAS DE VIDRO E FIBRAS DE POLI(ARAMIDA)}

Dissertação apresentada à Faculdade de Odontologia de Bauru da Universidade de São Paulo, como parte dos requisitos para a obtenção do título de Mestre em Odontologia - Área de Reabilitação Oral.

Orientador: Prof. Dr. Paulo Martins Ferreira 
Colán Guzmán, Paola del Rosario

C67a Avaliação da resistência à fratura de próteses fixas provisórias implanto-suportadas variando o comprimento do cantilever e o tipo de fibra: fibras de vidro e fibras de poli(aramida) / Paola del Rosario Colán Guzmán. -- Bauru, 2007.

146 p. : il. ; $30 \mathrm{~cm}$.

Dissertação (Mestrado) -- Faculdade de Odontologia de Bauru. Universidade de São Paulo.

Orientador: Prof. Dr. Paulo Martins Ferreira

Autorizo, exclusivamente pra fins acadêmicos e científicos, a reprodução total ou parcial desta tese, por processo fotocopiadores e/ou meios eletrônicos.

Assinatura do autor:

Data: 


\title{
PAOLA DEL ROSARIO COLÁN GUZMÁN
}

\author{
Nascimento \\ 31 de agosto de 1977 \\ Tacna - Perú \\ Filiação \\ Lucio Alberto Colán Gonzales \\ Haydeé Leontina Guzmán de Colán \\ $1995-2000$ \\ Curso de Odontologia \\ Faculdade de Odontologia. \\ Universidade Católica de Santa Maria - Perú. \\ $2002-2004$ \\ Curso de Especialização em Prótese Dentária \\ Faculdade de Odontologia de Bauru \\ Universidade de São Paulo - Brasil \\ $2004-2005$ \\ Professora da Faculdade de Odontologia \\ Universidade Católica de Santa Maria - Perú \\ $2005-2007$ \\ Curso de Pós-Graduação em Reabilitação Oral no \\ nível de Mestrado \\ Faculdade de Odontologia de Bauru \\ Universidade de São Paulo - Brasil \\ Associações \\ Colégio Odontológico del Perú \\ SBPqO - Sociedade Brasileira de Pesquisa \\ Odontológica \\ APCD - Associação Paulista de Cirurgiões \\ Dentistas
}




\section{Dedicatória}

À Deus, minha fonte de existência, por estar sempre ao meu lado, guiando cada passo no meu caminho, obrigada por todas as coisas que fazes por mim, por fazer de meus dias um eterno aprendizagem. Sem ti nada sou, mas com você tudo é possível.

À Virgem Maria, minha mãe do céu que nunca me deixa sozinha.

A meus pais Lucio e Haydeé, não existem palavras que o coração possa expressar todo o amor e admiração que tenho por vocês. Vocês são minha inspiração, meu exemplo de vida e o tesouro mais valioso que tenho. Obrigada por todo seu apoio incondicional, por acreditar sempre em mim, por me incentivar a correr detrás dos meus sonhos, por compartilhar comigo cada triunfo e cada fracasso. Obrigada também por todos os seus ensinamentos e por fazer de mim uma pessoa digna. Todo este tempo longe de vocês, serviu para valorizar a minha linda família, para valorizar todos os seus esforços inesgotáveis e todas as suas preocupações por mim. Todas as minhas conquistas não teriam sentido sem vocês do meu lado.

De coração, muito obrigada por tudo. Amo muito vocês. 
A minha irmã Karina, por compartilhar comigo cada sonho, por fazer suas as minhas preocupações, por torcer e rezar por mim sempre, você é minha melhor amiga, tenha certeza disso. Mesmo ficando fisicamente longe por muito tempo, sempre você ficou comigo no meu coração e nos meus pensamentos. Obrigada por teu carinho sincero, por as palavras de conforto cada vez que eu preciso e por estar sempre presente na minha vida. Amo você irmãzinha.

A meu grande amor, meu melhor amigo e colega de mestrado Fernando Freitas, por ser essa pessoa especial que entrou na minha vida para ser parte dela. Por me motivar e ajudar a crescer como pessoa e profissionalmente e pela sua colaboração na realização deste trabalho. Obrigada por teu amor, carinho, respeito, apoio incondicional, cumplicidade, por me ajudar a levantar e segurar minha mão nos momentos de fraqueza. Compartilhamos tantas coisas que na minha memória e no meu coração serão inesquecíveis, agradeço a Deus por ter colocado você no meu caminho. Obrigada por fazer minha vida muito mais feliz, mais completa. Te amo coração. 


\section{Agradecimentos Especiais}

Ao Sr. César Antunes de Freitas, Sra. Deolinda Furtado de Freitas, Márcia e Vitor, pessoas sinceras, exemplos de dignidade, que sempre me trataram como parte da família e me fizeram sentir como se estivesse em casa. Muito obrigada por ter me acolhido todo este tempo e nunca ter me deixado sozinha, por seu carinho, pelo apoio, pela preocupação. Vocês são a minha família Brasileira, meu carinho, meu respeito e meu profundo agradecimento são eternos.

Vocês têm e terão sempre um lugar especial no meu coração. 


\section{Agradecimento Especial}

Ao Prof. Dr. Paulo Martins Ferreira, pela sua valiosa orientação, ensinamentos e estímulo constante para a realização e culminação deste trabalho. Agradeço sua amizade, sua confiança depositada em mim e sua disponibilidade em todos os momentos que precisei. Muito obrigada. 
"As escolhas que você fez o trouxeram para onde você está hoje. Mas as escolhas que você vai fazer a partir de agora, podem levá-lo para qualquer lugar onde você quiser ir. Embora você possa sentir-se preso e sem forças, essa não é a verdadeira situação. Você pode escolher superar os obstáculos. Você pode escolher seguir seu sonho." 


\section{Agradecimentos}

À Faculdade de Odontologia de Bauru, da Universidade de São Paulo, representada pelo Prof. Dr. Luiz Fernando Pegoraro, que tornou possivel a concretização do meu sonho profissional.

\section{Aos Membros da Banca examinadora,}

Pela disponibilidade e presteza em avaliar a minha tese, partilhando comigo suas experiências e contribuindo ainda mais para a finalização deste trabalho.

Ao Prof. Dr. Luiz Fernando Pegoraro, homem de grande mérito no âmbito profissional e pessoal, pela condução de seus ensinamentos e orientações.

A todos os professores do Departamento de Prótese, Milton Carlos Gonçalves Salvador, José Henrique Rubo, Carlos dos Reis Pereira de Araújo, Vinícius Carvalho Porto, Wellington Cardoso Bonachela, Lucimar Falavinha Vieira, Renato Freitas, Accácio Lins do Valle, Gerson

Bonfante, Paulo Conti, por todos os ensinamentos essenciais para a minha formação profissional.

Ao Prof. Dr. César Freitas, pelo carinho e amizade sincera, pela transmissão de conhecimentos e conselhos na vida acadêmica e pessoal. Obrigada de coração pela sua disponibilidade em me ajudar sempre que precisei. Suas lições estarão sempre comigo. Minha profunda gratidão.

Ao Departamento de Materiais Dentários, lugar aconchegante e com boa vibração, onde foi possível a realização da parte laboratorial deste trabalho, muito obrigada aos professores, funcionários e alunos que conformam este digno departamento por me receber sempre com um sorriso, por me permitir usar as instalações e aparelhos sempre que precisei. Muito obrigada. 
Ao Prof. Dr. José Roberto Pereira Lauris, pela orientação na confecção da análisis estatística deste trabalho.

Aos meus colegas de mestrado, Luciana, Adrianinha, Rafael, Gabi, Thiago, Valeria, Daniel B, Dudu, Flora, Daniel, Buda, Ana Paula e Romão, pelo convívio e amizade.

Aos meus colegas de Doutorado, em especial à Katita e Paty, pela amizade sincera.

Aos meus colegas veteranos de Mestrado, em especial à Tânia, Livia e Mikaela, pela bonita amizade que construímos.

Aos colegas e amigos do Departamento de Materiais Dentários, em especial à Márcia e Breno, pessoas de alto astral, amigos sinceros dentro e fora da faculdade, obrigada pelo carinho e amizade sincera.

A todos os colegas de outras áreas, pela alegria de compartilharmos os bons e difíceis momentos do curso.

A meus amigos brasileiros: José Sergio, Aldry, Raquel, Lili, Henrique e Miguelito, pessoas especiais que Deus colocou no meu caminho, muito obrigada pela amizade, pelo carinho e por compartir momentos inesquecíveis.

A todos os meus pacientes, meu afeto e sincera gratidão.

Aos funcionários do Departamento de Prótese, em especial: Claudia, Reivanildo e Walquiria pela atenção e carinho a mim dispensados em todos os momentos. 
Aos funcionários do Departamento de Materiais Dentários, pela gentileza com que sempre me acolheram, em especial ao Alcides quem me ajudo de maneira prestativa sempre que precisei. Muito obrigada.

Aos funcionários da Biblioteca pela solicitude e profissionalismo.

Aos funcionários da Pós Graduação da FOB pela atenção e sempre disponibilidade, em particular a Giane, Letícia, Meg, Eduardo e Hebi.

A CNPq, pelo apoio financeiro essencial para a concretização dessa etapa da minha vida.

A todos os funcionários da Faculdade de Odontologia de Bauru, que com gentileza atendem às nossas solicitações.

Às empresas comerciais "Ângelus" $\boldsymbol{e}$ "Neodent", pela disponibilidade, por atenderem prontamente meus pedidos e por me facilitar os seus produtos odontológicos para a confecção deste trabalho. Seu apoio foi fundamental para a concretização deste trabalho. Muito obrigada.

A todas as pessoas que direta ou indiretamente contribuíram para a realização deste trabalho.

Muito obrigada. 


\section{SUMÁRIO}

\section{LISTA DE FIGURAS}

LISTA DE TABELAS

LISTA DE ABREVIATURAS E SÍMBOLOS

RESUMO

1 INTRODUÇÃO

2 REVISÃO DE LITERATURA 29

3. PROPOSIÇÃO 69

4 MATERIAL E MÉTODOS 73

5 RESULTADOS 97

6 DISCUSSÃO 103

7 CONCLUSÃO

ANEXOS 121

REFERÊNCIAS BIBLIOGRÁFICAS 133

ABSTRACT 145 


\section{LISTA DE FIGURAS}

Figura 1 - Vista oclusal da matriz em aço para a confecção dos espécimes 75

Figura 2 - Vista lateral (vestibular) da matriz em aço, parafusos e chave para fixação dos análogos 75

Figura 3 - Vista lateral (lingual) da matriz em aço 75

Figura 4 - Vista vestibular do enceramento para obtenção da matriz de silicone ... 77

Figura 5 - Vista oclusal do enceramento 77

Figura 6 - Vista interior da parte superior e inferior da matriz de silicone 77

Figura 7 - Vista lateral de matrizes de silicone antes de ser acopladas 77

Figura 8 - Parte superior da matriz de silicone 77

Figura 9 - Parte inferior da matriz de silicone que será articulada com a matriz de aço 77

Figura 10 - Articulação da matriz de silicone sobre a matriz de aço 78

Figura 11 - Análogo, componente protético para confecção do provisório, e parafuso Neodent ${ }^{\circledR}$ 78

Figura 12 - Detalhe da fibra de poli(aramida) Kevlar ${ }^{\circledR}$ Du Pont ${ }^{\circledR}$....... 80

Figura 13 - Detalhe da fibra de vidro Fibrante ${ }^{\circledR}$ Ângelus ${ }^{\circledR}$ - Odontológika Ind. Ltda. . 80

Figura 14 - Vista oclusal do posicionamento das fibras do grupo Kevlar 85

Figura 15 - Vista oclusal do posicionamento das fibras do grupo Fibrante 85

Figura 16 - Vista frontal mostrando o posicionamento das fibras sobre as matrizes de silicone e metálica 85 
Figura 17 - Injeção da resina na base da matriz de silicone e sobre as fibras previamente posicionadas 85

Figura 18 - Injeção da resina através do orifício na parte superior da matriz de silicone até o seu extravasamento 85

Figura 19 - Extravasamento da resina pelos orifícios superiores da matriz de silicone .. 85 Figura 20 - Disposição das matrizes após a completa inserção da resina, com a apreensão de suas partes através de uma placa de vidro e um frasco contendo $500 \mathrm{~g}$ de chumbo 86

Figura 21 - Vista oclusal do espécime, após a polimerização da resina, simulando prótese parcial fixa provisória com um cantilever de $21 \mathrm{~mm}$ de comprimento 86 Figura 22 - Vista frontal do espécime após a remoção das matrizes utilizadas para a sua confecção 86

Figura 23 - Vista frontal do espécime após o acabamento com a remoção dos excessos de resina 87

Figura 24 - Vista oclusal do espécime após o acabamento 87

Figura 25 - Mensuração do espécime após o acabamento: altura do conector 87

Figura 26 - Paquímetro digital padronizando a altura do conector 87

Figura 27 - Mensuração do espécime após o acabamento: largura do conector .... 87

Figura 28 - Paquímetro digital padronizando a largura do conector 87

Figura 29 - Vista frontal do espécime colocado na matriz de aço, pronto para ser submetido ao teste de resistência à fratura 88

Figura 30 - Vista oclusal do espécime colocado na matriz de aço 88

Figura 31 - Balança com precisão de 0,001 g (Sauter ${ }^{\circledR}$, model K1200, Switzerland) utilizada para a mensuração da resina 88 
Figura 32 - Balança modelo 2662 fabricada por Sartorius-Werke AG (Göttingen, Alemanha), com capacidade máxima de $200 \mathrm{~g}$ e acuidade de 0,0001g utilizada para a mensuração das fibras 88

Figura 33 - Fixação dos provisórios aos seus respectivos análogos. Os parafusos de fixação receberam torque de $32 \mathrm{~N} / \mathrm{cm}$ 91

Figura 34 - Torque de $32 \mathrm{~N} / \mathrm{cm}$ realizado com torquímetro Neodent ${ }^{\circledR}$ - Brasil ........ 91 Figura 35 - Máquina universal de ensaios $\operatorname{Kratos}^{\circledR}$ (Kratos - Dinamômetros Ltda. São Paulo - SP), utilizada para os ensaios de resistência à fratura 91

Figura 36 - Espécime fixado sobre a matriz de teste, com a esfera posicionada a 1,0 $\mathrm{mm}$ da extremidade distal da crista marginal do cantilever, para exercer a carga durante o ensaio de resistência à fratura 91

Figura 37 - Vista frontal mostrando a fratura na região do conector mesial, quando a carga foi exercida (cantilever $7 \mathrm{~mm}$ ) 91

Figura 38 - Vista oclusal mostrando a fratura na região do conector mesial, quando a carga foi exercida (cantilever $7 \mathrm{~mm}$ ) 91

Figura 39 - Detalhe da fratura do tipo Parcial apresentada pelos espécimes do grupo Fibrante 93

Figura 40 - Detalhe da fratura do tipo Parcial apresentada pelos espécimes do grupo Kevlar 93

Figura 41 - Detalhe da fratura do tipo Total Separada apresentada pelos espécimes do grupo controle (sem reforço) 93

Figura 42 - Médias dos valores de resistência à fratura (Kgf) dos grupos estudados 98 


\section{LISTA DE TABELAS}

Tabela 1 - Descrição do material de reforço utilizado e divisão dos grupos 79

Tabela 2 - Divisão dos grupos em função dos parâmetros avaliados: comprimento do cantilever e reforço utilizado 80 Tabela 3 - Valores das médias e desvio padrão da resistência à fratura dos grupos

Tabela 4 - Análise de variância (ANOVA) dos resultados da resistência à fratura dos espécimes 99

Tabela 5 - Comparações individuais obtidas através do Teste de Tukey, com nível de significância de 0.05 99 Tabela 6 - Ocorrência, em porcentagem, do modo de fratura apresentado pelos grupos 100 


\title{
LISTA DE ABREVIATURAS E SÍMBOLOS
}

\author{
$\% \quad$ Por cento \\ $\varnothing \quad$ Diâmetro \\ AgPd Prata- paládio \\ ASTM Associação Americana para Teste de Materiais \\ Bis-GMA Resina bis glicol metacrilato \\ $\mathrm{cm} \quad$ Centímetro \\ $\mathrm{CoCr} \quad$ Cobalto-cromo \\ g gramas \\ HEMA 2- hidroxietil metacrilato \\ Kgf Quilograma força \\ $\mathrm{ml} \quad$ mililitro \\ $\mathrm{mm} \quad$ Milímetro \\ $\mathrm{mm} / \mathrm{min} \quad$ Milímetro por minuto \\ MMA Monômero metilmetacrilato \\ $\mathrm{N} \quad$ Newton \\ $\mathrm{N} / \mathrm{cm} \quad$ Newton centímetro \\ n $\quad$ Número \\ ${ }^{\circ} \mathrm{C} \quad$ Graus Celsius \\ $p \quad$ Nível de significância \\ Pd Cu Paládio-cobre \\ PEMA Poli(etilmetacrilato) \\ PMMA Poli(metilmetacrilato) \\ UCLA University of California, Los Angeles
}


RESUMO 


\section{RESUMO}

No tratamento reabilitador oral as restaurações provisórias são de suma importância. A resistência e a longevidade dos materiais utilizados em sua execução são críticas, principalmente em tratamentos prolongados e em espaços desdentados extensos. O objetivo deste trabalho foi avaliar a resistência e o modo de fratura de espécimes que simularam uma prótese fixa de três elementos variando o comprimento do cantilever ( 7,14 e $21 \mathrm{~mm})$, confeccionadas em resina acrílica poli(metilmetacrilato) (PMMA) autopolimerizável, com e sem reforço em seu interior, construídos sobre componentes para implantes. Os reforços utilizados foram: fibras de vidro (Fibrante $\AA^{-}$Ângelus $\AA$, Londrina, PR, Brasil) e fibras de poli(aramida) (Kevlar $®$ Du Pont ${ }^{\circ}$, USA). Os grupos foram constituídos de 10 espécimes cada, incluindo um grupo controle, sem reforço. Os espécimes foram submetidos à carga compressiva até a fratura. A análise dos resultados (ANOVA, $p<0,05$ ), para o teste de resistência, mostrou não haver diferença estatística entre os grupos com respeito ao tipo de reforço, sendo que houve diferença estatística significante no que respeita ao comprimento do cantilever. Quando o comprimento do cantilever foi de $7 \mathrm{~mm}$ todos os grupos apresentaram os valores médios de resistência a fratura, em $\mathrm{N}$, significativamente maiores que os apresentados pelos grupos com 14 e $21 \mathrm{~mm}$ de comprimento. Em relação ao modo de fratura os grupos reforçados apresentaram fraturas mais favoráveis ao reparo, tendo sido do tipo Parcial.

Palavras-chave: Resinas acrílicas. Restauração Dentária Temporária. Estresse mecânico. 


\section{INTRODUÇÃO}

Em qualquer procedimento reabilitador as restaurações provisórias assumem importância relevante, pois servem como orientação para o tratamento definitivo. Nesta fase de coroas provisórias são avaliados os problemas fonéticos; os aspectos funcionais: função, parafunção, deglutição, mastigação, retenção de alimentos e higienização; os aspectos estéticos: posição dos dentes, cor, brilho, textura, gengiva, harmonia facial, linha do sorriso, apoio de lábio; funcionando como protótipo ao redor do qual os tecidos moles podem ser avaliados e condicionados. As restaurações provisórias devem apresentar: (1) polimento adequado e adaptação precisa, evitando o acúmulo de placa bacteriana; (2) desenho adequado para resistir aos esforços mastigatórios sem desgaste ou fratura evitando a necessidade de consertos ou confecção de outro provisório; (3) possibilidade de reembasamento, quando na necessidade de reparos e ajustes; (4) baixo custo e (5) estética aceitável ${ }^{3}$.

Quando o tratamento reabilitador e realizado a través de implantes osseointegrados, a utilização de restaurações provisórias se faz necessária por dois motivos principais: a necessidade de um direcionamento estético da gengiva e a exposição progressiva de implantes à carga funcional ${ }^{12}$. Em áreas onde a qualidade óssea é questionável e há suspeitas quanto à longevidade do implante, os provisórios podem servir para "testar" a osseointegração antes da realização da prótese definitiva. As próteses provisórias 
sobre implantes servem ainda para auxiliar na escolha do pilar ideal (para os sistemas de duas fases); e para avaliar a remodelação óssea e os tecidos periimplantares durante o período final da osseointegração ${ }^{12,44}$.

Problemas relacionados à disponibilidade de tecido ósseo para a colocação de implantes osseointegrados, situação econômica ou próprios conceitos do paciente têm tornado necessário o uso de próteses com extensões em cantilever.

Em quaisquer estruturas sujeitas as cargas funcionais, podem ocorrer situações que produzirão sobrecargas e complicações subseqüentes. O tratamento com implantes osseointegrados implica em uma estrutura baseada em tecido biológico (osso) e componentes mecânicos (implante e restauração protética). Sobrecarga neste sistema biomecânico pode ser definida como uma condição onde forças de mastigação exercem uma torção repetida em parte da estrutura, levando à perda óssea marginal e/ou falha dos componentes.

O êxito clínico dos implantes é amplamente determinado, pela maneira como o estresse mecânico é transferido do implante, ao tecido ósseo circundante, sem gerar forças de grande magnitude, o que poderia colocar em risco a longevidade do implante e da prótese.

Em próteses implanto-suportadas, as forcas oclusais concentram-se nas extensões em cantilever e, com isso, há uma maior incidência de fratura da infra-estrutura, na união entre o implante mais distal e a extremidade livre ${ }^{57}$ 
Os materiais utilizados na confecção das próteses provisórias devem fornecer uma boa adaptação marginal e conforto; promover resistência ao deslocamento durante a função; exibirem boa estabilidade dimensional; não ser poroso; apresentar-se esteticamente aceitável em relação à escolha de cor; facilidade de manipulação e de reparo; ser relativamente barato; ser biocompatível. Alguns desses requisitos, assim como a resistência à fratura e rigidez suficientes para cumprirem a sua função com conforto, são extremadamente importantes, e muitas vezes ditam o sucesso do tratamento ${ }^{10}$.

A resina poli(metilmetacrilato) (PMMA) tem sido geralmente eleita para a confecção das restaurações provisórias. Quando estas são exigidas por um longo tempo e se estendem por vários dentes, com longos vãos, a resistência e a estabilidade das próteses realizadas com este material, entretanto, se tornam críticas em função do processo de fadiga que são submetidas através do ciclo mastigatório ou uma eventual parafunção ${ }^{26,27,38,58 .}$

Estas resinas PMMA, por tanto apresentam baixa resistência à fratura sob a influência de cargas oclusais. Em razão disso, diversos autores propõem a inclusão de reforços nesses polímeros, tais como fios de aço ${ }^{11,20,34,54}$, fibras de carbono ${ }^{14,27,47,54,60}$, fibras de poli(aramida) $)^{1,6,23,34,47,54}$, fibras de poli(etileno $)^{1,13,38,43,51}$, fibras de vidro ${ }^{1,23,24,25,32,47,52,53,54}$, fibras de sílica ${ }^{56}$, fibras de alumínio $^{17}$, bandas ortodônticas ${ }^{20}$ e fibras de nylon ${ }^{23}$ com a finalidade de melhorar suas propriedades mecânicas, dentre elas, a resistência flexional e o módulo de elasticidade, traduzidos pela resistência á fratura e rigidez, respectivamente ${ }^{19}$ 
A capacidade desses reforços baseados em fibras de vidro e de poli(aramida) $\left(\right.$ Kevlar $\left.^{\circledR}\right)$ de melhorar as propriedades mecânicas da resina parece depender, principalmente, da orientação e do arranjo das fibras e da união destas com a resina. Pesquisas têm sido realizadas para se determinar as variáveis que comprometem ou influenciam positivamente as propriedades mecânicas das próteses provisórias reforçadas por essas fibras, com o propósito principal de se desenvolver tanto materiais quanto técnicas que permitam uma maior longevidade dessas restaurações. 
2 REVISÃO DE LITERATURA 


\section{REVISÃO DE LITERATURA}

\subsection{Importância da prótese provisória no tratamento reabilitador implanto- suportado}

Qualquer tipo de tratamento protético exige a confecção de restaurações provisórias, as quais facilitam a confecção da prótese definitiva e, conseqüentemente levam-na ao êxito ${ }^{58}$. Durante o uso das próteses provisórias, os contornos, textura, tipo de conexão e desenho oclusal podem ser modificados, até se alcançar um estágio de qualidade capaz de satisfazer plenamente as exigências biomecânicas e estéticas. A prótese provisória deve, portanto, antever o resultado final, sendo protótipo da prótese definitiva ${ }^{26}$. É conhecido que as restaurações provisórias apresentam ou trazem algumas desvantagens, principalmente se permanecerem por um longo período na boca. Podem ocorrer fraturas que se tornam mais freqüentes à medida que sua permanência na boca é prolongada ${ }^{33}$. Portanto, dada a sua importância, é imperativo elaborar próteses temporárias com a mesma diligência com que se trabalham as próteses definitivas dando-lhes as mesmas características de qualidade ${ }^{46,10}$.

Assim como no tratamento reabilitador sobre pilares dentais, o sucesso das restaurações implanto-suportadas é resultado da disciplina e da 
compreensão na abordagem do diagnóstico e plano de tratamento, da precisão cirúrgica, dos procedimentos restauradores, bem como da sua contínua manutenção. O uso prudente e adequado da etapa de transição em que são utilizadas as próteses provisórias é um fator importante para se atingir o sucesso clínico e boa aceitação do tratamento protético com implantes pelo paciente ${ }^{15}$. Com isso, a prótese provisória serve de referencial no planejamento e confecção da prótese definitiva ${ }^{31,}$

As próteses provisórias sobre implantes osseointegrados ajudam no diagnostico e permitem que a restauração protética seja avaliada no que se refere ao desenho e contorno. Elas também permitem uma adaptação do paciente à condição dentada, possibilitando a graduação da força aplicada sobre os implantes. Segundo Binon ${ }^{8}$, em 1990, o tempo requerido por uma prótese provisória sobre implantes pode ser comparado ao de uma prótese provisória sobre dentes naturais. Dependendo da complexidade do caso, é possível confeccionar uma restauração provisória direta ou indireta, sendo que o ideal é compô-las com cilindros temporários metálicos (componentes metálicos para provisórios), provendo resistência adequada por meio de reforços metálicos, de fibras de vidro ou de polímeros orgânicos ${ }^{15}$. 


\subsection{Utilização de reforços nas resinas acrílicas para a confecção das próteses provisórias}

Segundo Burns, Beck, Nelson, em 2003 ${ }^{10}$, muitas dessas resinas acrílicas utilizadas para a confecção de restaurações provisórias são mecanicamente frágeis e pouco resistentes à fratura. A propagação de trincas que culmina com a fratura desse material é decorrência de sua inadequada resistência transversa e incapacidade de suportar fadiga por período de tempo mais prolongado.

Grant; Greener ${ }^{17}$ foram autores de um dos primeiros relatos da utilização de algum tipo de reforço em resinas acrílicas baseadas em PMMA no universo Odontológico. Realizaram, em 1967, um estudo avaliando a resistência flexional de resinas acrílicas PMMA auto e termopolimerizáveis quando reforçadas com fibras à base de alumínio denominadas "sapphire whiskers". Os autores submeteram espécimes em forma de barra ao teste de carga de três pontos. Evidenciaram em seus resultados um aumento considerável da resistência flexional das resinas acrílicas que continham uma pequena concentração dessas fibras. Os autores relataram ainda a importância do uso de silano para as propriedades mecânicas dos compostos reforçados. Descreveram que a aplicação de silano sobre o reforço aumenta sua atividade superficial deste, permitindo uma melhor transferência das tensões da matriz de PMMA para as fibras. 
Em 1984, Carroll; Von Fraunhofer ${ }^{11}$ estudaram o efeito do uso de fios metálicos de diversos diâmetros, unidirecionais ou trançados, com e sem dobras circulares em suas extremidades, sobre a resistência flexional de espécimes em resina acrílica PMMA autopolimerizável. Os fios mediam 0,41; 0,64;0,91; e 1,30 mm de diâmetro. Foram confeccionados espécimes em forma de barra por meio da técnica da saturação e os diversos fios foram posicionados no seu terço inferior. De acordo com os autores, essa localização dos fios permite uma maior resistência do espécime às forças de tração. Após a realização de um teste de carga de três pontos para a verificação da resistência flexional das amostras, constatou-se o aumento significativo na resistência da resina quando esta foi reforçada com fios de diâmetros a partir de 0,41 mm, com dobra na extremidade. O maior valor médio de resistência foi encontrado com a utilização do fio de maior diâmetro. Nenhuma vantagem foi observada na confecção de dobras nas extremidades dos fios. Observou-se, por fim, que o uso dos fios trançados aumentou a resistência, tendo sido, entretanto, um aumento clinicamente questionável.

Em 1990, Berrong, Weed, Young ${ }^{6}$, relataram que as resinas PMMA tem sido aplicadas com sucesso em varias áreas da Odontologia. São materiais de fácil manipulação, porém, com algumas propriedades mecânicas limitadas. Sustentaram que as áreas críticas de próteses realizadas com essas resinas, como as regiões de pouca espessura devem ser reforçadas prevenindo fraturas. Os autores elaboraram um estudo para avaliar o efeito de diversas concentrações, em peso, de fibras à base de poli(aramida) na resistência ao impacto de espécimes confeccionados em resina acrílica PMMA termo-polimerizável. 
Nos espécimes com fibras nas concentrações de $1 \%$ e $2 \%$ as fraturas foram em "galho verde" mantendo os dois fragmentos unidos. Todas as amostras reforçadas foram significantemente mais resistentes que o grupo controle não reforçado, sendo que, quanto maior concentração da fibra, maior foi a resistência ao impacto. Segundo os autores, tal material composto de fibras sintéticas de poli(aramida), tem sido indicado para restaurações dentárias onde a resistência é essencial. Essas fibras têm maiores valores de módulo de elasticidade e resistência à tração que o aço, e por isso tem sido empregadas na fabricação de vestimentas à prova de bala, pneus automotivos, mastros de embarcações e partes de aeronaves.

Henry; Bishop; Purt ${ }^{21}$, em 1990, destacaram que os materiais indicados para a confecção de próteses provisórias estão sempre sujeitos à fadiga e à fratura, particularmente em regiões com espessuras menores e sob efeito de maiores cargas oclusais. Os autores citaram que o método usual de se reforçar essas próteses com fios e malhas metálicas normalmente resulta em sobrecontorno da restauração, dificultando a sua utilização. Ao contrário, defendem o uso de fibras baseadas em polímeros de alto peso molecular como fator de redução do risco de fraturas e falhas das restaurações em resina, principalmente quando utilizadas por longos períodos. Os autores executaram testes de resistência à tração e de resistência flexional em alguns materiais utilizados para confecção de próteses provisórias, incluindo uma resina PMMA autopolimerizável, contendo fibras de poli(etileno). Em ambos os ensaios, testou-se o tratamento dessas fibras com silano. A inclusão de fibras de poli(etileno) silanizadas do tipo longa e unidirecional 
resultou em espécimes mais resistentes à tração e à flexão. O uso de fibras não silanizadas, porém, diminuiu essas propriedades. Os autores afirmaram que a silanização provoca uma adesão química entre as fibras e a matriz resinosa reduzindo o micro-deslizamento entre elas e, portanto, minimiza a propagação de micro-trincas que, futuramente, podem acarretar numa fratura de todo o conjunto.

Dixon, Breeding ${ }^{13}$, em 1992, ressaltaram o uso crescente de vários tipos de reforço de resinas baseadas em PMMA. Relataram, contudo, que as fibras de carbono e as de poli(aramida), apesar de sua eficiência comprovada sobre as propriedades mecânicas da resina PMMA, não podem ser usadas em áreas estéticas, a primeira por sua coloração negra e a segunda por sua coloração amarelada. Os autores investigaram a resistência flexional de três resinas acrílicas utilizadas para a confecção de bases de próteses totais quando reforçadas com fibras de poli(etileno). Utilizaram uma resina de alta resistência ao impacto, uma resina termo-ativada de polimerização rápida e uma resina foto-polimerizável. Encontraram em seus resultados que a incorporação das fibras de poli(etileno) aumento significativamente a resistência flexional somente da resina fotopolimerizável.

Vallittu, Lassila ${ }^{54}$, em 1992, declararam que a resina PMMA é freqüentemente reforçada com diferentes tipos de fios metálicos e com fibras de carbono. O uso das fibras de carbono, entretanto, é limitado esteticamente pela sua coloração negra. Relataram que por essa razão deve-se utilizar reforços que forneçam uma estética mais apropriada, como as fibras de vidro e as de poli(aramida). 
Os autores usaram fios metálicos semicirculares, fios metálicos achatados e trançados, fios metálicos cilíndricos de 1,0 mm de diâmetro e uma malha metálica, todos esses, lisos ou jateados com óxido de alumínio, além disso, utilizaram fibras de vidro contínuas e trançadas, fibras trançadas de carbono e fibras trançadas de poli(aramida), com e sem tratamento superficial com silano. Testaram a eficiência de todos esses reforços na resistência flexional de uma resina PMMA através de um teste de carga de três pontos.

Observaram que todos os fios metálicos aumentaram significativamente a resistência à flexão dos espécimes, porém, não houve diferencia estatística entre os lisos e os jateados. A malha metálica, contrariamente, não apresentou boas propriedades mecânicas. Com relação às fibras, todas elas reforçaram os espécimes em resina com exceção das fibras de vidro não silanizadas que, ao contrário, diminuíram levemente sua resistência à flexão. As fibras posicionadas de maneira perpendicular ou diagonal à carga não resultaram em diferença nesta resistência. Por fim, concluíam que nenhuma das fibras estudadas teve um efeito tão favorável na resistência à flexão quanto os fios metálicos.

Vallittu ${ }^{47}$, em 1993, argumentou que a resistência à flexão das próteses provisórias reforçadas com fibras depende da adesão entre a matriz da resina acrílica e a fibra utilizada, e que essa adesão poderia ser melhorada por meio de tratamento dessas fibras com compostos de silano. O autor pesquisou o efeito do uso de duas fórmulas de silano, A174 e AP133, na adesão entre diferentes tipos de fibras e uma resina à base de PMMA. Realizou-se o teste de resistência flexional em espécimes em forma de barra, reforçados por fibras de vidro, carbono e 
poli(aramida), todas unidirecionais. Evidenciou-se que somente o composto A174 aumentou significativamente a adesão entre a resina e as fibras de vidro e poli(aramida), porém nenhum dos tipos de silano causou efeito relevante na união entre as fibras de carbono e a resina.

Powell et al. $^{34}$, em 1994, relataram que as próteses provisórias devem ter, entre outras características, resistência mecânica aos esforços mastigatórios, já que em algumas circunstâncias são utilizadas por alguns meses durante o tratamento protético reabilitador. Elaboraram um estudo utilizando próteses fixas provisórias em PMMA reforçadas com fio de aço de 0,9 mm de diâmetro, fibras de poli(aramida) (Kevlar) além de um grupo sem reforço. Avaliaram a rigidez inicial, a carga no momento da fratura inicial e a unidade de tenacidade, esta última descrita pelos autores como a energia armazenada pela viga da prótese após ter sofrido uma deflexão de 1,0 mm. Observou-se que as próteses provisórias com reforços em configuração de "V" - acompanhando a inclinação da própria prótese e, com isso, mantendo-se o mais inferiormente possível - exibiram maior rigidez. O grupo reforçado com o fio 0,9 apresentou rigidez significativamente maior. Não houve diferença estatística entre os valores da carga gerada na primeira fratura. Os autores justificaram os resultados baseando-se na "Lei de flexão das vigas". Segundo os autores, a referida lei declara que quando uma viga está sob ação de uma carga compressiva no centro e eqüidistante entre dois pontos de suporte, a força aplicada induz tensão de compressão na região superior e tensão de tração na região inferior. Os reforços utilizados nas resinas odontológicas são mais eficientes quando posicionados fora do eixo neutro no interior da prótese, o mais inferiormente 
possível em relação ao centro. Freqüentemente a fratura tem início no lado de tração, por isso, os espécimes cujos reforços foram posicionados na região mais inferior apresentaram maior resistência à fratura do que aqueles cujos reforços situavam-se mais próximos à superfície oclusal.

Vallittu; Lassila; Lappalainen ${ }^{55}$, em 1994 , citam que as fibras para reforço deveriam ser utilizadas com o propósito de aumentar a resistência flexional e a rigidez dos materiais poliméricos. Os autores defendem que uma ótima adesão entre as fibras e a matriz do polímero é essencial para o aumento da resistência mecânica. Essa adesão, por sua vez, pode ser conseguida e aumentada pelo uso de um composto de silano. A fim de se compreender o efeito da quantidade de fibras sobre a resistência dos polímeros utilizados em Odontologia, os autores estudaram a resistência flexional de espécimes confeccionados em resina acrílica PMMA termo-polimerizável reforçados com fibras de vidro, fibras de poli(aramida) e fibras de carbono, todas unidirecionais. As fibras foram inseridas no centro do espécime, no sentido vertical, utilizando três concentrações em peso, a depender do tipo de reforço. Os autores observaram em seus resultados, que a incorporação de qualquer uma dessas fibras na resina acrílica aumentou estatisticamente sua resistência à flexão, sendo que esse aumento foi diretamente proporcional à concentração das mesmas. Não foram encontradas diferenças significativas entre os tipos de reforços. Evidenciou-se, porém, a presença de bolhas na interface fibraresina onde se localizou a fratura. Os autores atribuíram a presença dessas bolhas à contração de polimerização do monômero metilmetacrilato no qual as fibras foram 
imersas antes de sua incorporação à massa da resina acrílica, que é de cerca de 20\% contra $8 \%$ do polímero PMMA.

Vallittu $^{48}$, ainda em 1994, dando continuidade ao trabalho anterior, pesquisou a influência da imersão prévia das fibras em monômero sobre a resistência flexional do espécime em resina acrílica. O autor questionou, inicialmente, se a diferencia de contração de polimerização entre a resina mais fluida, em contato direto com as fibras, e a resina que compõe o restante do provisório provocaria uma redução da resistência flexional do espécime. As fibras foram silanizadas e tratadas, antes da confecção do corpo de prova, de duas maneiras: imersão no monômero ou numa mistura polímero/monômero. Concluiu-se que, diminuindo a contração de polimerização da resina que fica em contato com as fibras, aumenta-se a resistência à flexão do corpo de prova. Essa contração pode ser amenizada pela imersão das fibras numa mistura de polímero/monômero, variando-se a proporção em peso (de 3:8 a 10:8), antes da polimerização do espécime. Por fim, observou-se que a imersão em uma mistura polímero/monômero fornece uma camada mais espessa de resina na superfície da fibra de vidro do que a imersão em monômero apenas.

Vallittu ${ }^{49}$, em 1995, elaborou um estudo para estabelecer a relação entre o tempo de polimerização e a resistência flexional de espécimes em resina acrílica PMMA termo-polimerizável reforçadas com fibras de vidro unidirecionais e silanizadas. Comparou-se a resistência flexional após processos de polimerização de 45 minutos, 2, 6 e 12 horas, a $80^{\circ} \mathrm{C}$ e após processos de 6 e 12 horas, com imersão dos espécimes em água fervente durante os 30 minutos finais. 
Averiguaram-se também as causas e efeitos dos espaços vazios internos nos corpos de prova reforçados. Dentro do mesmo grupo, com e sem reforço, a resistência não variou significativamente em relação ao tempo de polimerização. Também não houve relação entre a presença de bolhas de ar entre as fibras e a resistência flexional, fortalecendo a hipótese, de que a resistência flexional é influenciada principalmente pelo contato entre a superfície das fibras e a matriz resinosa, e não pelo contato entre as fibras.

Hazelton et al. $^{20}$, em 1995, refere que a resina acrílica PMMA tem sido o material de escolha para a realização de próteses provisórias. Vários materiais e técnicas de reforço têm sido sugeridos. Os autores acrescentam que reforços realizados através de estruturas metálicas fundidas implicam em maior custo e tempo de confecção. Investigaram o efeito de algumas variáveis experimentais sobre o desempenho de próteses provisórias em PMMA autopolimerizável, com distância inter-pilares de 23,0 mm: 1) prótese reforçada com fio ortodôntico $0,8 \mathrm{~mm}$ de diâmetro e 2) prótese reforçada com uma fita metálica para confecção de bandas ortodônticas. Avaliou-se a carga quando foi perdido o selamento marginal do cimento nos pilares mesial e distal, além de registrarem a rigidez e a carga no momento da fratura destas próteses. Observou-se que as próteses reforçadas com as matrizes metálicas foram estatisticamente mais rígidas e necessitaram de maior carga para perder o selamento marginal nos pilares. Nenhuma diferença significativa foi notada na resistência à fratura entre as próteses com e sem reforço, entretanto, os autores relataram que os reforços mantiveram as 
duas peças fraturadas contíguas. Clinicamente, isso reduziria o risco de perda, ingestão ou aspiração da prótese provisória.

Segundo Samadzadeh et al. $^{38}$, em 1997, os materiais restauradores provisórios geralmente exibem baixa resistência à fratura, especialmente em casos de próteses com vãos extensos, de longa duração, localizadas em áreas de maior estresse mastigatório ou em pacientes que apresentam bruxismo. Porém, com a utilização de fibras de diversas composições e desenhos, tem-se aumentado a resistência desses materiais. Os autores avaliaram o efeito do uso de uma fibra trançada à base de poli(etileno) tratada com plasma sobre a resistência à fratura de corpos de prova simulando próteses provisórias com vãos de $22 \mathrm{~mm}$. Os corpos de prova foram confeccionados em PMMA autopolimerizável e em um material restaurador provisório de polimerização dual à base de Bis-GMA. Os tipos de fratura foram analisados e classificados da seguinte forma: (a) parcial, quando a região de conexão da prótese permaneceu intacta e uma porção vestibular ou lingual do pôntico fraturou, separando-se da prótese; (b) não separada, quando houve fratura de um ou ambos os conectores, porém, o conjunto permaneceu unido pela fibra que não se fraturou e (c) catastrófica, quando o pôntico sofreu uma fratura dividindo-o em várias partes que se separaram da prótese. Ao final, verificou-se que o reforço de poli(etileno) aumentou significantemente a resistência à fratura das próteses confeccionadas no material Bis-GMA. No grupo confeccionado com resina acrílica PMMA autopolimerizável, o reforço não conferiu aumento estatisticamente significativo dessa resistência. Todavia, os autores enfatizam que, em ambos os 
grupos reforçados, o modo de fratura foi mais favorável, ou seja, do tipo parcial ou não separada.

Vallittu ${ }^{50}$, ainda em 1997, apresentou resultados preliminares de um estudo clínico que avaliou a utilização de fibras de vidro unidirecionais e silanizadas no reparo das bases de doze próteses totais e dez próteses parciais removíveis. A avaliação foi feita após 13 meses de uso, em média. Muitas das próteses utilizadas nesse estudo já tinham história de fratura recorrente de sua base em PMMA. Houve recorrência da mesma fratura somente em duas próteses. Em outras seis, as fraturas ocorreram em novas posições. Com base nesses resultados o autor suporta o uso dessas fibras no reparo de próteses removíveis, totais ou parciais, observando cuidadosamente as áreas de maior tensão, nas quais elas devem ser inseridas. O autor finaliza relatando que, apesar dos resultados serem promissores, há necessidade de uma avaliação mais longa.

Vallittu ${ }^{51}$, em 1997, estudou a influência da inclusão de fibras trançadas de poli(etileno) de alto peso molecular, tratadas com gás de plasma, sobre a resistência flexional de espécimes em resina acrílica PMMA autopolimerizável. As fibras, em uma ou duas camadas, foram inseridas no terço inferior dos corpos e o ensaio realizado foi um teste compressivo de carga de três pontos. Os resultados evidenciaram uma melhora, embora modesta, na resistência flexional dos espécimes. Baseado na análise microscópica eletrônica de varredura dos espécimes fraturados, o autor atribuiu o pequeno aumento na resistência dos espécimes à falta de união adequada entre a matriz resinosa e a fibra. 
Miettinen; Vallittu ${ }^{29}$, em 1997, relataram que a resina acrílica PMMA tem sido utilizada como matriz polimérica para compostos reforçados com fibras. O uso dessa resina, entretanto, apresenta alguns problemas, já que uma das dificuldades encontradas é a inadequada impregnação das fibras pela matriz de PMMA. A efetiva impregnação das fibras permitiria um contato mais íntimo com a matriz aumentando a resistência do composto. Um dos mecanismos para melhorar a adesão entre as fibras e o PMMA é a aplicação de uma solução fluida de PMMAMMA sobre a fibra ou sua imersão em monômero MMA. Essas duas técnicas, porém, aumentam a quantidade de monômero residual e a sua conseqüente liberação do composto resina-fibra. Com a proposta de estudar esse problema, os autores realizaram uma pesquisa para determinar a liberação de monômero MMA residual em água, por espécimes em resinas acrílicas PMMA auto e termopolimerizáveis, com e sem a adição de reforço à base de fibras de vidro. Utilizou-se barras com fibras de vidro contínuas, unidirecionais e silanizadas, umedecidas com cerca de 10 gotas de monômero antes de sua incorporação à resina. As amostras em resina termo-ativada foram imersas em água fervente por 45 minutos, enquanto os espécimes em resina autopolimerizável foram polimerizados sob pressão e temperatura de $45^{\circ} \mathrm{C}$, durante 10,30 e 60 minutos. O ciclo de polimerização foi determinante no conteúdo de monômero residual liberado. Um menor tempo de polimerização resultou em uma maior liberação desse monômero. Nos espécimes reforçados obtidos com a resina ativada quimicamente, a quantidade de monômero residual foi semelhante àqueles sem reforço, entretanto a liberação de monômero nas amostras termo-ativadas, com e sem reforço, foi significantemente menor que as autopolimerizáveis. 
De acordo com Vallittu ${ }^{52}$, em 1998, a utilização de fibras como reforço dos polímeros odontológicos tem fornecido melhores resultados mecânicos do que os fios metálicos. Determinou-se resistência à fratura de corpos de prova semelhantes a próteses provisórias de três unidades com vãos de 10,0 $\mathrm{mm}$, sendo dois pilares e um pôntico, quando reforçados apenas com fibras de vidro unidirecionais ou associadas à forma trançada. Utilizou-se uma mistura de pó da resina PMMA e líquido do monômero n-butilmetacrilato, e as fibras foram distribuídas de três formas: uma, duas ou três fibras unidirecionais. Foram também confeccionados espécimes contendo três fibras unidirecionais e uma trançada. A vantagem das fibras empregadas nesse estudo seria a sua pré-impregnação com um monômero que possibilita maior adesão à matriz polimérica. Os corpos de prova foram submetidos a um teste compressivo de carga de três pontos. Observou-se que a adição das fibras aumentou significativamente a resistência à fratura das próteses, embora, segundo o autor, o posicionamento das fibras não tenha sido o ideal, ou seja, não foram inseridas na sua parte inferior onde se concentraram as tensões de tração. Por fim, o uso da fibra trançada próxima aos pilares aumentou a resistência dos retentores.

Em 1998, Stipho ${ }^{42}$ mencionou os diversos tipos de fibras utilizados com a finalidade de melhorar as propriedades mecânicas das resinas à base de PMMA utilizadas em próteses provisórias. Segundo o autor, as fibras de poli(aramida) e carbono são reforços eficazes, porém não fornecem uma boa estética, assim como os fios e malhas metálicas, que normalmente exigem um sobrecontorno em regiões menos espessas da prótese. As fibras de poli(etileno), 
apesar de fornecerem características estéticas ao composto reforçado, não são práticas, exigindo cuidados na sua manipulação. Por outro lado, defendeu que as fibras de vidro apresentam maior potencial como reforço das restaurações provisórias. O autor procurou estudar o efeito de diversas concentrações de fibras de vidro na forma de pequenos feixes, nas propriedades mecânicas de uma resina autopolimerizável à base de PMMA. Avaliou-se a resistência flexional, a deformação e o módulo de elasticidade dos espécimes em resina, variando a concentração em peso $(1 \%, 2 \%, 5 \%, 10 \%$ e $15 \%)$ das fibras na sua mistura. Encontrou-se um aumento significativo na resistência flexional dos grupos reforçados com as concentrações de $1 \%$ e $2 \%$ de fibras, ao passo que, maiores concentrações provocaram diminuição dessa resistência. Além disso, a deformação no momento da fratura foi estatisticamente maior no grupo com a concentração de $1 \%$. $\mathrm{O}$ autor finalizou ratificando que altas concentrações de fibras de vidro incorporadas à mistura da resina resultam na perda de homogeneidade e aumento da porosidade, provocando a redução de sua resistência.

Vallittu; Ruyter; Ekstrand ${ }^{56}$, em 1998, determinaram as propriedades flexionais de dois polímeros à base de PMMA, um auto e outro termopolimerizável, quando reforçados com fibras de vidro contínuas ou com fibras de sílica, em função do tempo de armazenamento em água. Espécimes em forma de barra foram submetidos a um teste de carga de três pontos para avaliação do limite da resistência flexional à fratura, após a imersão em água destilada, durante 2, 4, 12, 24 e 48 semanas. Em seus resultados, observou-se que o armazenamento em água diminuiu significativamente a resistência flexional dos espécimes sem reforço, 
evidenciando o efeito plastificante resultado da interação das moléculas de água com a estrutura do polímero. A resistência flexional também decresceu nos espécimes reforçados, tanto com as fibras de vidro quanto com as de sílica, tendo que os reforçados com fibras de sílica sofreram maior redução de resistência. Verificou-se ainda que a adesão entre as fibras e a matriz da resina diminuiu com a imersão em água, porém os espécimes reforçados com fibras de vidro sofreram menor redução na adesão. Os autores explicaram que as regiões das fibras que não sofreram uma boa impregnação pela resina causaram porosidades que, provavelmente, aumentaram a absorção de água levando à diminuição da resistência flexional, sendo que as fibras de sílica apresentaram-se menos impregnadas pela resina do que as fibras de vidro.

Vallittu ${ }^{53}$, em 1999, relatou que a resistência flexional dos polímeros à base de PMMA usados em próteses provisórias pode ser ligeiramente aumentada pelo uso de reforços metálicos, entretanto, a influência desses reforços sobre a resistência à fadiga é questionável. As fibras de vidro, por sua vez, podem oferecer tanto características estéticas quanto melhores propriedades mecânicas, incluindo aumento da resistência à fadiga. Um dos requisitos para a eficiência dessas fibras é que elas mantenham uma ótima união com a matriz do polímero PMMA. A boa impregnação das fibras, portanto, concorre pelo aumento dessa adesão. Motivado por essa afirmativa, o autor pesquisou a resistência à flexão de polímeros à base de PMMA auto e termopolimerizáveis utilizados para a confecção de bases de próteses totais e fixas provisórias, quando reforçados com um sistema de fibras de vidro unidirecionais e trançadas, pré-impregnadas com um polímero 
poroso. A impregnação presente na superfície das fibras facilita o molhamento pela mistura polímero/monômero. Esse molhamento leva à plastificação, por dissolução, da camada de polímero poroso. Após a obtenção dos espécimes, segundo as normas ISO, realizou-se o teste de carga de três pontos. Observou que ambos os reforços aumentaram significativamente a resistência flexional dos polímeros estudados. A resistência encontrada com as fibras unidirecionais foi maior que a oferecida pelas fibras trançadas. A análise microscópica eletrônica, por fim, evidenciou que ambas as fibras foram bem impregnadas pela matriz do polímero utilizado.

Uzun; Hersek; Tinçer ${ }^{45}$, em 1999, compararam o efeito de cinco tipos de reforços sobre a resistência flexional de espécimes confeccionados com uma resina à base de PMMA termopolimerizável. Os corpos de prova foram reforçados com fibras entrelaçadas à base de vidro, de carbono, de poli(aramida) (delgada e espessa) e de poli(etileno). Nenhuma das fibras melhorou estatisticamente essa propriedade em relação ao grupo controle.

Nohrström; Vallittu; Yli-Urpo ${ }^{32}$, em 2000, defenderam que a qualidade das próteses parciais fixas provisórias depende de uma boa integridade marginal, adequada rigidez e resistência suficiente para resistir às cargas mastigatórias. A rigidez e a resistência são resultados do tipo de polímero e do possível tipo de reforço utilizado. Os autores concordaram que os polímeros mais utilizados são baseados em PMMA ou em uma variação do mesmo. No que diz respeito aos reforços, explicaram que as fibras de poli(etileno) apresentam a desvantagem de não permitir uma boa adesão entre a matriz polimérica e sua 
superfície. As fibras de vidro, ao contrário, por possibilitarem a sua silanização apresentam uma boa adesão com a matriz de PMMA, aumentando seu potencial de reforço desses materiais. Os autores, sustentados por essas informações, estudaram a influência da posição e do número de fibras de vidro com arranjos unidirecionais ou entrelaçados, na resistência à fratura de próteses provisórias confeccionadas com uma mistura do polímero PEMA e o monômero nbutilmetacrilato. Avaliou-se, além disso, a influência da distância entre os pilares sobre a resistência e o posicionamento das fibras: na superfície oclusal dos preparos dos pilares, na superfície inferior do pôntico e em ambas as posições. Foram confeccionadas próteses com vãos de 10,0, 17,0 e 19,5 mm. Os autores concluíram que a utilização de fibras posicionadas na parte inferior do pôntico, associadas a um primeiro reforço localizado próximo à superfície oclusal dos pilares, aumentou a resistência à fratura dos corpos de prova. A eficiência dos reforços foi mais evidente quando se utilizaram próteses com vãos mais extensos.

Lastumäki, Lassila, Vallittu ${ }^{28}$, em 2001, defenderam que é necessário se reforçar os polímeros utilizados na Odontologia, em função de suas propriedades mecânicas inadequadas, tais como a resistência à flexão e a rigidez. Avaliaram as propriedades mecânicas de uma resina à base de poli(amida) reforçada com fibras de vidro, indicada para a confecção de próteses parciais fixas em resina, quando armazenada por 3 meses em água ou ambiente seco. Utilizaram espécimes retangulares em forma de barra que foram submetidos a um teste de carga de três pontos para registro da resistência flexional e do módulo de elasticidade. Observaram que o armazenamento em água diminuiu 
significativamente ambas as propriedades estudadas. A absorção de água, segundo os autores, pela resina poli(amida) pode resultar em uma hidrólise de sua cadeia polimérica, aumentando a degradação da superfície das fibras, e promovendo um efeito plastificante da matriz da resina.

Segundo Bae et al $^{1}$, em 2001, a maneira como as fibras participam do aumento da resistência à fratura de uma resina é dependente da composição dessa fibra, de sua orientação, concentração em peso, e de sua adesão com a matriz resinosa. O efeito de diversos reforços, com diferentes composições e desenhos, com e sem pré-impregnação de sua superfície, na resistência flexional e no módulo de elasticidade de uma resina composta, foi objeto de seu estudo. Utilizaram uma fibra de poli(etileno), uma fibra de poli(aramida) ou Kevlar e três fibras de vidro. Do total, apenas duas fibras foram pré-impregnadas com uma matriz Bis-GMA. Os reforços foram posicionados no terço inferior dos espécimes em forma de barra, que após 24 horas de sua confecção e imersos em água destilada, foram submetidos a um teste de carga de três pontos. Em seus resultados, observaram que em relação ao módulo de elasticidade, ou seja, a sua rigidez, uma das fibras de vidro pré-impregnadas e as fibras de poli(aramida) geraram valores maiores que as demais. O uso da fibra de poli(etileno), por sua vez, mostrou uma diminuição dessa propriedade quando comparado ao grupo controle, sem reforço. No que diz respeito à resistência flexional, as fibras de poli(aramida) resultaram nas maiores médias, seguidas das fibras de vidro. Os autores discutem que quando uma resina reforçada com fibras é utilizada na confecção de uma prótese parcial fixa em regiões de maior estresse mastigatório, deve ser recomendado um material com alta resistência à 
flexão e alto módulo de elasticidade. As fibras de poli(aramida) e as fibras de vidro parecem ser materiais recomendados para esse fim. Os resultados, entretanto, obtidos através de um teste estático têm uma aplicabilidade limitada à área clinica em função do modo como a força é aplicada. Por fim, sugerem mais estudos, incluindo os testes de fadiga.

John, Gangadahar, Shah ${ }^{23}$, em 2001, realizaram um estudo para determinar se a resistência flexional de uma resina PMMA autopolimerizável para base de dentadura poderia ser melhorada por meio do reforço com três tipos de fibras. Foram preparados dez espécimes de dimensões similares para cada um dos quatro grupos experimentais: (controle) resina acrílica convencional; grupo de resina acrílica reforçada com fibras de vidro; grupo de resina acrílica reforçada com poli(aramida) e grupo de resina acrílica reforçada com fibras de nylon. O teste de resistência flexional foi realizado através de um teste de carga de três pontos. O grupo reforçado com fibras de vidro apresentou valores significativamente maiores de resistência flexional, seguido pelos grupos reforçados com poli(aramida), com nylon e pelo grupo sem reforço (controle), não havendo diferença entre os dois últimos grupos. Os autores concluíram que o reforço da resina para base de dentadura com fibras de vidro, poli(aramida) ou nylon aumenta a sua resistência flexional. O tipo de fibra mais indicado depende do tipo de prótese a ser confeccionada. As fibras de vidro e poli(aramida) parecem ser adequadas para uso em próteses totais e extensões distais de próteses parciais removíveis. O reforço com fibra de vidro também parece prevenir fraturas em próteses fixas provisórias devido ao aumento da resistência na área dos conectores. 
Bastos, Ferreira ${ }^{2}$, em 2003, estudaram o efeito de diversos reforços sobre a resistência flexional e o tipo de fratura de uma resina PMMA autopolimerizável indicada para a confecção de próteses provisórias, por meio de um teste de carga de três pontos estabelecido pela norma ISO n. 10477. A análise estatística mostrou que os grupos reforçados com fio metálico de $\varnothing 0,7 \mathrm{~mm}$, fibra de vidro trançada impregnada e fibra de poli(etileno) tratada superficialmente com plasma aumentaram significativamente a resistência flexional. Os grupos reforçados com fibra de vidro unidirecional e com fio de amarrilho metálico trançado não influenciaram essa propriedade. As fraturas dos espécimes reforçados foram consideradas mais favoráveis ocorrendo de forma predominante os tipos Ausente e Parcial.

Keyf, Uzun e Mutlu²4, em 2003, avaliaram a resistência transversal de uma resina PMMA autopolimerizável reforçada com fibra de vidro submetida a dois tipos de tratamento superficiais. Foram empregados dois tipos diferentes de agentes de modificação química para criar uma superfície mais hidrofílica nas fibras de vidro: o HEMA e o ar atmosférico. Os espécimes foram armazenados em água destilada à temperatura ambiente e testados 24 horas depois de sua confecção por meio de um teste de carga de três pontos. Encontraram diferenças estatisticamente significativas entre os grupo quanto à resistência flexional. O grupo reforçado com fibras de vidro tratadas com HEMA obteve valores significativamente maiores que grupo sem reforço. Os autores concluíram que o tratamento da fibra pode aumentar sua energia de superfície por meio da modificação química dessa superfície. O tratamento de superfície é um gás 
parcialmente ionizado que contém íons, elétrons e outras espécies neutrais com muitos níveis de energia. Quando energizados por um campo elétrico, radicais livres, íons e átomos são formados e podem interagir com as superfícies sólidas que sejam colocadas no plasma. Isso resulta em modificações da química da superfície do sólido, nesse caso, da fibra de vidro. O aumento da energia de superfície é responsável pela maior reatividade química e compatibilidade com outros materiais. Assim, os tratamentos com monômero HEMA e ar atmosférico aumentaram a resistência flexional de espécimes em resina PMMA. As fibras sem tratamento agem como corpos incluídos na resina acrílica e, ao invés de lhe conferir resistência, enfraquecem-na, por quebrarem sua homogeneidade.

Kim, Watts ${ }^{25}$, em 2004, examinaram o efeito da inclusão de uma fibra de vidro e do armazenamento em água sobre a tenacidade à fratura de resinas para restaurações provisórias. Os autores empregaram quatro resinas: três baseadas em polímeros de dimetacrilato e uma à base de monometacrilato. Foram utilizados espécimes em forma de barra com entalhes na sua parte inferior. Os valores de tenacidade à fratura do grupo reforçado foram significativamente superiores aos do grupo controle (não reforçado). Da mesma forma que no grupo não reforçado, o armazenamento em água ocasionou uma pequena e gradual redução na resistência à tenacidade dos grupos reforçados, porém sem significância. Os autores concluíram que a tenacidade à fratura das resinas utilizadas em seu estudo aumentou significativamente quando as mesmas foram reforçadas com fibras de vidro unidirecionais. O desempenho desses materiais 
reforçados mostrou-se satisfatório mesmo após o armazenamento em água por até dois meses.

Hamza et al. ${ }^{18}, 2004$, consideram que as fraturas nas restaurações provisórias, especialmente nas próteses parciais fixas de vãos longos ou submetidos a maiores cargas oclusais são um importante problema clínico. Os autores têm sugerido diferentes técnicas para reforçar as restaurações provisórias, entretanto, o efeito dessas técnicas ainda não está claro. Assim, realizou-se um estudo cujo objetivo foi determinar a tenacidade à fratura e a resistência flexional de três tipos de resinas (PMMA, PEMA e Bis-GMA) para restaurações provisórias, reforçadas com diferentes fibras comercialmente disponíveis: duas fibras de vidro silanizadas e pré-impregnadas na forma unidirecional e trançada; três fibras de poli(etileno) tratadas com plasma e, por fim, uma fibra de poli(etileno) silanizada e tratada com plasma. Para o teste de tenacidade à fratura, foram fabricadas barras de acordo com as Especificações da Associação Americana para Testes de Materiais (ASTM). Para o teste de resistência flexional, foram fabricados espécimes retangulares de acordo com a norma ISO 10477. Como resultado, os autores verificaram que, quanto à tenacidade à fratura, exceto os grupos reforçados com a fibra de vidro trançada e uma das fibras de polietileno tratadas com plasma, não houve diferenças significativas entre os grupos com e sem reforço. Quanto à resistência flexional, a resina PMMA reforçada resultou em valores significativamente maiores do que a resina PMMA sem reforço, exceto para o grupo reforçado com a fibra de vidro trançada. Quanto à resina de PEMA, dentre os espécimes reforçados, somente um dos grupos reforçados com fibra de poli(etileno) 
tratada com plasma não apresentou diferença significativamente maior que o grupo controle. A resistência flexional dos espécimes reforçados de PEMA foi significativamente maior que a dos não reforçados, exceto para os grupos com reforço de fibra de vidro trançada e uma das fibras de poli(etileno). A tenacidade à fratura dos espécimes de resina Bis-GMA reforçados foi significativamente maior que a dos não reforçados, exceto para o grupo reforçado com fibra de vidro trançada e com uma das fibras de poli(etileno) tratadas com plasma. Com relação à resistência flexional, os grupos que não apresentaram diferença estatística foram aqueles que utilizaram uma fibra de vidro trançada e duas das fibras de poli(etileno) tratadas somente com plasma. Em sua discussão, os autores ressaltam que as fibras usadas nesse estudo apresentavam diferentes formas e tratamentos de superfície e concluem que o uso das fibras de reforço tratadas superficialmente é um método efetivo de aumentar a tenacidade à fratura e a resistência flexional das restaurações provisórias de resina.

Narva et al. ${ }^{30}$, em 2005, estudaram a resistência flexional de uma resina PMMA autopolimerizável indicada para a confecção de bases de prótese totais, quando associada a diferentes tipos de fibras. Foram confeccionados espécimes em forma de barra adicionando-Ihes fibras de poli(etileno) sem tratamento superficial; fibras de vidro impregnadas com um polímero poroso; fibras de vidro impregnadas com um monômero foto-polimerizável e fibras de vidro com um sistema de resina foto-polimerizável. As fibras foram orientadas longitudinalmente no interior dos corpos de prova, sendo que, em um grupo, elas foram inseridas na região submetida às tensões de compressão e no outro, na 
região das tensões de tração. Os resultados mostraram que o tipo e a localização da fibra para reforço influenciaram estatisticamente a resistência flexional. As fibras impregnadas obtiveram melhores resultados, significantes em relação ao grupo associado com as fibras sem impregnação e ao grupo sem reforço.

\subsection{Utilização clínica dos diversos tipos de reforços nas próteses implanto- suportadas confeccionadas em resinas odontológicas}

Björk, Ekstrand e Ruyter ${ }^{9}$, em 1986, alertaram para o alto custo exigido na confecção de próteses implanto-suportadas com infra-estruturas fundidas em ouro. Os autores propuseram o uso de fibras de carbono/grafite associadas às resinas PMMA para a fabricação dessas próteses. Argumentava-se que essas fibras apresentavam, além de baixo custo, propriedades mecânicas e biocompatibilidade adequadas. Baseados nessas afirmações estudou-se o comportamento clínico de próteses sobre implantes compostas por PMMA reforçado por fibra de carbono/grafite. Onze pacientes (três homens e oito mulheres) participaram do estudo, todos desdentados totais, exceto por uma mulher que possuía uma prótese de 12 unidades na arcada superior. Oito pacientes receberam cinco implantes de titânio e três receberam seis implantes de titânio, todos na mandíbula. Foi realizado o ajuste oclusal e, após uma semana, a primeira consulta de controle. As consultas de controle subseqüentes foram realizadas 1, 3, 7, 12 e 24 
meses após a instalação das próteses. Os dados coletados relacionavam-se à avaliação subjetiva do tratamento por meio de critérios clínicos relacionados à mobilidade do implante, saúde gengival e estado da prótese. Foram realizadas radiografias periapicais e panorâmicas antes do tratamento e após 12 meses de avaliação. A avaliação clínica revelou as seguintes informações: todas as próteses apresentaram oclusão e estabilidade satisfatórias. Nenhuma complicação técnica foi registrada. Não houve acúmulo excessivo de placa sobre as próteses. A maioria dos pacientes estava satisfeita com o tratamento, com exceção de três pacientes que acharam a prótese muito volumosa. Nestes pacientes, o ajuste do tamanho das próteses levou a uma maior satisfação na consulta de retorno, após 14 dias. Os exames radiográficos não mostraram qualquer radioluscência entre o tecido ósseo e os implantes. Os tecidos gengivais marginais estavam saudáveis, exceto por uma leve inflamação e sangramento à sondagem encontrados em dois intermediários em dois pacientes, relacionados à higiene inadequada em conseqüência do formato desfavorável dos pônticos. Os autores concluíram que próteses reforçadas com fibras de carbono/grafite podem ser uma alternativa às infra-estruturas fundidas convencionais nas reabilitações protéticas realizadas na mandíbula.

Ainda em 1986, Ruyter, Ekstrand e Björk ${ }^{37}$, utilizaram sistemas de resina PMMA reforçada com fibras de carbono/grafite (FCG) na confecção de próteses fixas implanto-suportadas e comparam suas propriedades de contração de polimerização e resistência flexural com resinas auto e termopolimerizáveis sem reforço. Avaliou-se o efeito da adição de diferentes concentrações (em peso) das fibras de carbono/grafite sobre essas propriedades. 
Foram estudados ainda a influência da temperatura de polimerização e o tempo de armazenamento em água sobre a estabilidade dimensional. Os grupos sem reforço exibiram pouca contração linear de polimerização, provavelmente devido à retenção dos espécimes na mufla durante a polimerização. Essa contração foi ainda menor nos espécimes reforçados. Durante a armazenagem em água, houve uma expansão linear mínima dos espécimes não reforçados, enquanto os espécimes reforçados não apresentaram qualquer expansão linear longitudinal, provavelmente devido à retenção longitudinal das dimensões do espécime pelas fibras presentes. Quando testados secos, houve um aumento significativo das propriedades flexionais dos espécimes à medida que se aumentava o conteúdo de fibra. Com o armazenamento em água, as propriedades flexionais de todos os grupos diminuíram, provavelmente em decorrência da absorção de água pela matriz polimérica e pelo efeito plastificante da água. A água absorvida também pode ter interagido com a superfície das fibras, levando a uma menor união entre as fibras e a matriz. Embora os espécimes reforçados tenham tido suas propriedades mecânicas reduzidas com o armazenamento em água, elas ainda eram superiores às propriedades dos materiais não reforçados. Não houve diferença nas propriedades flexionais entre os materiais auto e termopolimerizáveis contendo 20\% (em peso) de reforço. Assim, os autores concluíram que as próteses implanto-suportadas reforçadas com fibras de carbono/grafite podem ser uma alternativa às infra-estruturas fundidas convencionais.

Binon, Sullivan ${ }^{8}$, em 1990, descreveram uma técnica direta e outra indireta para a confecção de coroas provisórias em próteses parciais fixas 
implanto-suportadas, utilizando fibras com a finalidade de reforço. Na técnica direta os modelos de gesso são montados no articulador. Realiza-se um enceramento de diagnóstico e sua transferência para um novo modelo. Esse modelo é duplicado e uma matriz de dois $\mathrm{cm}$ de espessura é prensada a vácuo sobre o enceramento. Os intermediários provisórios são conectados aos implantes, intra-oralmente, pelos parafusos de ouro. A matriz é testada em posição e, sobre o sítio cirúrgico é colocado um lençol de borracha. Coloca-se silicona na abertura oclusal dos cilindros. A matriz é preenchida com resina autopolimerizável e assentada. A silicona é removida e os parafusos soltos após a presa inicial da resina. A prótese provisória é finalizada com as aberturas oclusais sendo preenchidas com nylon. Pela técnica indireta, os componentes de moldagem são colocados e os modelos obtidos. Os cilindros são colocados nos modelos, o enceramento é realizado, levado à mufla e prensado com a resina desejada. Os autores observam que, na presença de cantiléveres ou vãos longos, há necessidade da inclusão de fibras de poli(aramida) $\operatorname{Kevlar}^{\circledR}$. Nessas condições, o comprimento da fibra deve ser duas vezes o da prótese fixa, ficando a mesma embebida na resina, em forma de oito na região do pôntico.

Bergenda, Ekstrand, Ruyter ${ }^{5}$, em 1995, realizaram uma avaliação clínica longitudinal (32 a 56 meses) em pacientes tratados com implantes do tipo Brånemark e próteses feitas em PMMA associadas a uma fibra de carbono/grafite. Foram instaladas 27 dessas próteses em 25 pacientes, sobre 119 implantes. Após a instalação da prótese, três implantes localizados na maxila foram perdidos. Após um tempo médio em função de 44 meses, 19 próteses (70\%) ainda 
permaneciam in sito. Dentre as 19 próteses, cinco próteses fraturaram, das quais três foram trocadas e duas puderam ser reparadas. As fraturas foram percebidas precocemente após a carga e localizavam-se nos conectores mais distais, estendendo-se à interface dos intermediários. Os autores concluíram que as próteses em PMMA associadas às fibras de carbono/grafite podem ser uma alternativa reabilitadora que apresenta alta precisão, baixo custo e bons resultados estéticos. As propriedades mecânicas após períodos superiores aos três anos, não são satisfatórias, porém o método apresenta condições promissoras de desenvolvimento.

Behr et al. ${ }^{4}$, também em 2001, investigaram a resistência à fratura e a adaptação marginal de próteses confeccionadas em compósito e reforçadas por fibras de vidro, cimentadas ou parafusadas sobre implantes. O primeiro grupo consistiu de próteses reforçadas cimentadas com cimento resinoso sobre intermediários cônicos de titânio e o segundo grupo foi composto por próteses parafusadas. Após a ciclagem termo-mecânica simulando cinco anos de uso, todos os espécimes foram submetidos à carga até que fraturassem. Analisou-se a adaptação marginal por meio de microscopia de varredura. As próteses de quatro elementos cimentadas apresentaram resistência à fratura semelhante às próteses parafusadas. Da mesma forma a análise da adaptação marginal mostrou resultados similares para as próteses cimentadas e parafusadas. A adesão entre o material de cobertura (compósito) e o cimento resinoso deteriorou-se de forma significativa após a ciclagem termo-mecânica. Os autores concluíram que as próteses implanto- 
suportadas feitas com compósito reforçado por fibra de vidro, cimentadas ou parafusadas, podem se tornar uma alternativa às reconstruções metálicas.

Freilich et al. ${ }^{16}$, em 2002, explicam que o uso da tecnologia de compósitos reforçados por fibras para a criação de prótese sobre implantes livres de metal pode solucionar muito dos problemas associados à infra-estrutura metálica, tais como corrosão, toxicidade, complexidade de fabricação, alto custo e limitações estéticas. Os autores discutem que as pesquisas clínicas e laboratoriais evidenciam que esses materiais apresentam excelentes propriedades mecânicas e capacidade de unir-se quimicamente a outros materiais resinosos de cobertura usados na fabricação de próteses sobre implantes. Salientam ainda a necessidade de uma efetiva penetração e molhamento das fibras pela resina para que se obtenha um excelente desempenho mecânico. Assim, os autores propõem um sistema de fabricação de próteses sobre implantes parafusadas. Após o enceramento sobre os componentes provisórios, este é incluído e eliminado (técnica da cera perdida), deixando uma matriz para a injeção da resina de poli(metilmetacrilato) (PMMA) que ocupará o espaço da cera. A prótese é então, polimerizada, acabada e polida.

\subsection{Cantilever em próteses implanto-suportadas}

Skalak ${ }^{41}$, em 1983, num trabalho pioneiro na avaliação dos aspectos biomecânicos das próteses fixas implanto-suportadas analisou e discutiu a transmissão de tensão do sistema prótese e implantes osseointegrados ao tecido 
ósseo. Dentre as conclusões do autor destaca-se a dependência direta do número, arranjo, resistência dos implantes e forma de resistência da própria restauração protética na distribuição de cargas verticais e oblíquas a que está sujeita uma prótese fixa implanto-suportada. Segundo o autor, uma prótese com estrutura mais rígida possibilitaria a distribuição de tensões a diversos implantes mais efetivamente. Como o implante apresenta uma justaposição ao tecido ósseo a transmissão de tensões geradas por forças estáticas ou dinâmicas seria integral. Por outro lado, é importante a utilização de materiais resilientes, como a resina acrílica dos dentes artificiais, para que absorvam e distribuam de forma efetiva as cargas oclusais. Próteses com extensão em cantilever aumentam a carga no primeiro implante próximo a estes, de forma que cantilever moderados podem ser aceitos se os implantes forem suficientemente fortes.

Rangert; Jemt e Jorneus ${ }^{35}$, em 1989, afirmaram que o desenho das próteses e a posição dos implantes têm uma influência significativa sobre a tensão no tecido ósseo e nos próprios implantes. Os autores discutiram os parâmetros biomecânicos que determinam carga sobre os implantes, sugerindo os seguintes princípios clínicos a serem seguidos:

a) existem dois tipos principais de forças atuando sobre o implante e que devem ser consideradas: força axial e momento de torção. A força axial é mais favorável à medida que distribui tensão mais uniformemente, enquanto que o momento de torção promove tensão sobre o implante, bem como no tecido ósseo; 
b) próteses totais fixas mandibulares, as quais são sustentadas por implantes posicionados na região anterior e possuem cantilevers na região posterior, apresentam similaridades com uma alavanca Classe I. Os implantes mais posteriores em cada lado da prótese representam o fulcro da alavanca. Assim, os implantes imediatamente anteriores ao último irão receber uma força de tração proporcional ao braço de alavanca. Já os implantes mais posteriores serão submetidos a forças de compressão, que são a soma da força oclusal mais a força de tensão compensadora;

c) se mais de dois implantes dividem entre si a carga advinda do cantilever, a análise é mais complexa. Entretanto, o parâmetro crucial continua sendo o comprimento do cantilever em relação à distância entre os implantes mais anterior e mais posterior. Para uma dada distância, a margem de segurança aumentará com o aumento do número de implantes colocados;

d) momentos de torção são também induzidos por forças transversais. Nesta situação, o braço de alavanca será formado pela distância entre o contato oclusal e a união do intermediário com o implante, uma vez que a junção entre o parafuso de ouro e o parafuso do intermediário forma um conjunto único quando parafusados juntos;

e) o parafuso de ouro é o ponto mais fraco do sistema e fraturas devem ocorrer no mesmo, pois é facilmente reposto. A causa mais comum de fratura do parafuso de ouro é, provavelmente, seu afrouxamento. Se o parafuso fratura apesar de estar bem apertado, isso pode indicar imprecisão da infra-estrutura. Se o parafuso estiver bem apertado e a infra- 
estrutura bem adaptada e mesmo assim a fratura ocorrer, provavelmente está havendo sobrecarga no sistema. Neste caso, deve-se reavaliar a extensão do cantilever, o esquema oclusal e a posição dos implantes.

Para Bidez e Misch ${ }^{7}$, em 1992, a magnitude de força que é deletéria aos tecidos biológicos é desconhecida. Entretanto, uma regra simples é minimizar as forças de torção a que estão submetidos os implantes e a interface óssea sempre que possível. Isto porque os implantes estão sujeitos a um complexo sistema tri-dimensional de forças e momentos in vivo que afetam sua longevidade. As tensões geradas são influenciadas pelo tamanho das mesas oclusais, comprimento de cantilever, sistema de retenção e tipo de oclusão, entre outros fatores, e devem ser consideradas no plano de tratamento.

Shackleton et $\mathrm{al}^{40}$, em 1992, propuseram-se a verificar a natureza dos problemas protéticos e sua incidência, após a instalação de próteses fixas implanto-suportadas em um grupo de 25 pacientes, que foram tratados com próteses total fixa mandibular do Sistema Branemark. Os registros destes pacientes foram analisados em retrospectiva para coletar informações sobre tratamentos adicionais, num período de acompanhamento de 10 a 70 meses. Fratura de componentes protéticos individuais ou da própria prótese representaram $34,2 \%$ dos problemas relatados. Outras complicações incluíram o afrouxamento dos parafusos de ouro ou do intermediário $(25,5 \%)$, problemas dos tecidos moles $(9,6 \%)$, queixas em relação à fonética $(8,2 \%)$ e queixas estéticas (6,8\%). Uma análise da sobrevida demonstrou resultados significativamente melhores para as próteses com cantilever de $15 \mathrm{~mm}$ ou menos, comparadas com extensões mais longas que $15 \mathrm{~mm}$. Os 
autores concluíram que os resultados sugerem que mais de 50\% dos problemas protéticos estão relacionados aos fatores de estresse que atuam sobre a prótese. E que o comprimento do cantilever deveria ser limitados à $15 \mathrm{~mm}$, para minimizar a ocorrência de problemas mecânicos.

Como o comprimento da extremidade livre pode apresentar um efeito direto na perda óssea marginal, White; Caputo e Anderkvist ${ }^{59}$, em 1994, propuseram-se a investigar a transmissão de forças para a mandíbula. Um modelo, representando uma mandíbula humana edêntula foi confeccionado em resina fotoelástica. Cinco implantes do sistema Brånemark ${ }^{\mathrm{TM}}$, com 13mm de comprimento, foram colocados entre os forames mentonianos, sendo que os implantes do lado esquerdo foram dispostos ligeiramente mais próximos entre si que os do lado direito. Num plano sagital, os implantes do lado direito estavam perpendiculares ao plano oclusal e os do lado esquerdo, inclinados $5^{\circ}$ para distal. Uma infra-estrutura foi fundida em liga de PdCu e revestida com resina acrílica. Apresentava uma extensão máxima de $30 \mathrm{~mm}$ para posterior e $15 \mathrm{~mm}$ para anterior a partir dos implantes distais e pontos de aplicação de carga a cada $5 \mathrm{~mm}$. Uma força de $89 \mathrm{~N}$ foi exercida, nos locais pré-determinados até $30 \mathrm{~mm}$. Uma força de $134 \mathrm{~N}$ foi exercida nos pontos localizados na região anterior. Independente da extensão do cantilever, os autores observaram que a maior tensão concentrou-se na crista alveolar adjacente à superfície distal do implante terminal, no lado de aplicação da carga. Uma pequena quantidade de tensão também foi verificada na região apical destes implantes. Quando a carga foi aplicada na região anterior, a maior concentração de tensão localizou-se no implante mais próximo do ponto de aplicação da força. As pequenas variações na angulação dos implantes apresentaram efeitos distintos na magnitude 
da tensão. O implante terminal esquerdo, levemente inclinado para distal, exibiu maior concentração de tensão, que o implante terminal direito, posicionado mais verticalmente.

Van Zyl et ll $^{57}$, em 1995, através de uma análise tridimensional de elemento finito, verificaram a distribuição de tensões no tecido ósseo circundante aos implantes, os quais suportavam uma prótese total fixa com extremidade livre bilateral. Uma força estática vertical de $100 \mathrm{~N}$ era aplicado ao longo de toda a extensão do cantilever, a partir de $7 \mathrm{~mm}$ do implante terminal, até $25 \mathrm{~mm}$, em pontos localizados a cada $2 \mathrm{~mm}$. Os resultados deste estudo demonstraram que as tensões distribuídas nas áreas mesial e distal dos implantes foram consideravelmente inferiores às tensões transmitidas às porções vestibular e lingual. Os autores concluíram que extensões em cantilever superiores a 15mm podem propiciar uma maior produção de tensão na cortical lingual e, em menor grau, na cortical vestibular, o que poderia colocar em risco a integridades dos implantes.

Sertgöz e Güvener ${ }^{39}$, em 1996, investigaram a distribuição de tensão na interface implante/tecido ósseo através de uma análise tri-dimensional de elemento finito, onde foram utilizados três diferentes comprimentos de cantilever e implantes. Foram criados modelos de simulação de uma prótese fixa implantosuportada por seis implantes, embutidos em um modelo de osso mandibular (cortical e medular) e com cantilever posterior bilateral. Um total de nove modelos de simulação apresentavam três diferentes comprimentos de cantilever $(7 \mathrm{~mm}, 14 \mathrm{~mm}$ e $28 \mathrm{~mm})$ e três comprimentos de implantes $(7 \mathrm{~mm}, 15 \mathrm{~mm}$ e $20 \mathrm{~mm})$. Uma força de $75 \mathrm{~N}$ era aplicada, em direção perpendicular, na porção central e na região correspondente ao elemento mais posterior da extremidade livre. Uma força 
horizontal de $25 \mathrm{~N}$ era aplicada na superfície vestibular do elemento mais posterior do cantilever. As análises revelaram que as tensões máximas concentram-se na interface tecido ósseo/implante mais distal, localizada no lado de aplicação da carga. A tensão de tração máxima foi observada nas regiões mesial e distal tecido ósseo, quando uma carga vertical era aplicada, e nas regiões vestibular e lingual, sobre carga horizontal. O aumento do comprimento do cantilever resultou na elevação dos valores de tensão na interface implante/tecido ósseo. No entanto, o comprimento do implante não teve efeito significativo na distribuição da tensão nesta interface.

Seguindo na mesma linha de pesquisa, Jacques ${ }^{22}$ em 2000, realizou um trabalho cujo objetivo foi verificar a deformação em componentes de prótese fixa implanto-suportada, através de extensômetros, em função de duas ligas metálicas. Foram confeccionados corpos de prova simulando infra-estruturas de prótese fixa mandibular, em liga de $\mathrm{AgPd}$ e $\mathrm{CoCr}$ que foram posicionadas sobre um modelo mestre de alumínio. Uma carga estática vertical de $100 \mathrm{~N}$ foi aplicada na extremidade livre, a uma distância de 10, 15 e $20 \mathrm{~mm}$ para distal do centro do intermediário terminal. Os resultados encontrados mostraram que em extensões grandes de cantilever, a liga de $\mathrm{CoCr}$ apresentou um padrão de distribuição de forças semelhante a liga de AgPd com cantilever curto. Independente do local de aplicação da força e do tipo de liga utilizado na confecção das infra-estruturas, o intermediário mais próximo do ponto de aplicação da força foi o que registrou maior deformação específica. O emprego de uma liga mais rígida na confecção de infraestruturas de prótese fixa implanto-suportadas permite braços em cantilever mais extensos. 
Rubo $^{36}$, em 2004, realizou um estudo onde analisou as tensões em prótese sobre implantes, pelo método de elemento finito, utilizando um estudo paramétrico de sete variáveis clinicas: módulo de elasticidade do osso medular, comprimentos dos intermediários e implantes, comprimento do cantilever, numero e arranjo dos implantes, grau de curvatura da mandíbula e liga da infraestrutura (AgPd ou CoCr). Uma carga vertical de $100 \mathrm{~N}$ foi usada para simular a força oclusal. Foram usados comprimentos de cantilever de $10 \mathrm{~mm}, 15 \mathrm{~mm}$ e $20 \mathrm{~mm}$. Dentre os resultados o autor destacou que a cada incremento de $5 \mathrm{~mm}$ no comprimento do cantilever, a tensão aumenta aproximadamente 30 a 37\% no osso cortical ao redor dos implantes. O mesmo efeito foi observado nos intermediários. O aumento da tensão na infra-estrutura não foi proporcional ao aumento do braço do cantilever. 
3 PROPOSIÇÃO 


\section{PROPOSIÇÃO}

Considerados os aspectos observados na literatura consultada, este estudo laboratorial tem como finalidade:

a) Avaliar a resistência à fratura de próteses fixas provisórias implanto-suportadas confeccionadas em resina acrílica autopolimerizável variando:

a.1) o comprimento do cantilever,

a.2) o tipo de fibra de reforço (fibras de vidro Fibrante ${ }^{\circledR}$ Ângelus ${ }^{\circledR}$, Londrina, PR, Brasil e fibras de poli(aramida) Kevlar $^{\circledR}-$ Du Pont ${ }^{\circledR}$, USA).

b) Analisar e classificar o modo de fratura apresentados pelos espécimes dos diferentes grupos. 
4 MATERIAL E MÉTODOS 


\section{MATERIAL E MÉTODOS}

Para a realização deste trabalho, foram confeccionados espécimes simulando próteses parciais fixas provisórias sobre implantes de três elementos (canino, primeiro pré-molar e segundo pré-molar), com extensões de cantilever para distal de 7,14 e $21 \mathrm{~mm}$ de comprimento, utilizando o material e o método descritos a seguir.

\subsection{Obtenção da matriz metálica para confecção e ensaio dos espécimes}

Com o auxílio do Serviço Nacional de Aprendizagem Industrial (SENAI), foi fabricada uma matriz metálica em aço temperado que pudesse ser utilizada na confecção dos corpos de prova e no ensaio de resistência à fratura, servindo de base para fixação dos espécimes.

A matriz apresentou dimensões de $55 \mathrm{~mm}$ de comprimento, $30 \mathrm{~mm}$ de largura e $15 \mathrm{~mm}$ de altura, contendo três orifícios (4 mm de diâmetro e 15 $\mathrm{mm}$ de comprimento) perpendiculares à base para inserção dos análogos do implante com hexágono externo. A distância entre os centros dos orifícios foi de 7,0 mm. Lateralmente, a matriz apresentou três orifícios (dois no lado vestibular e um no lado lingual) nos quais foram inseridos parafusos com 4,0 mm de diâmetro, paralelos à base, para auxiliar na fixação dos análogos (Figuras 1, 2 e 3). Para permitir a 
deformação do corpo de prova na extremidade do cantilever, onde será aplicada a carga, foi feito um alivio na parte superior da matriz, correspondente à extremidade livre. Posteriormente, as próteses provisórias confeccionadas sobre os análogos, durante o ensaio mecânico, foram fixadas nesta matriz metálica. 


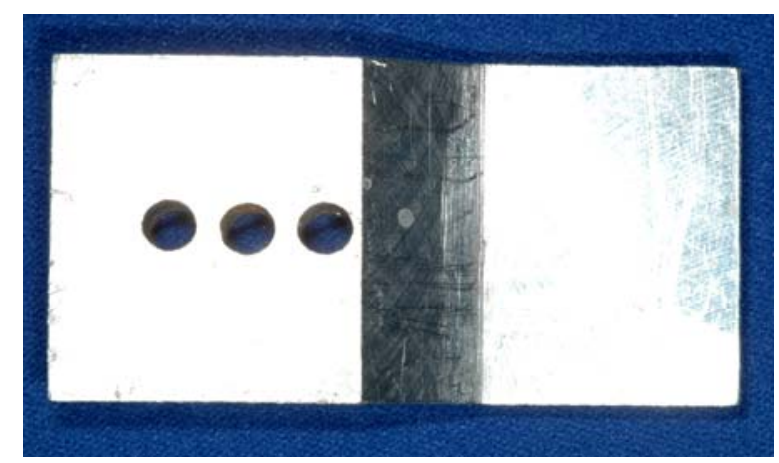

Figura 1 - Vista oclusal da matriz em aço para a confecção dos espécimes

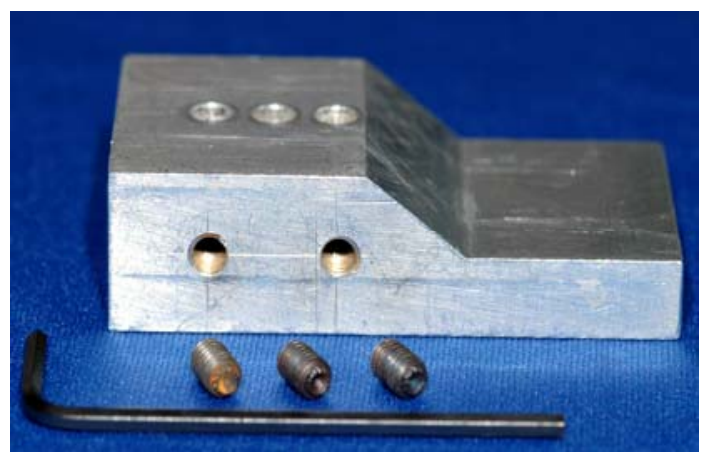

Figura 2 - Vista lateral (vestibular) da matriz em aço, parafusos e chave para fixação dos análogos

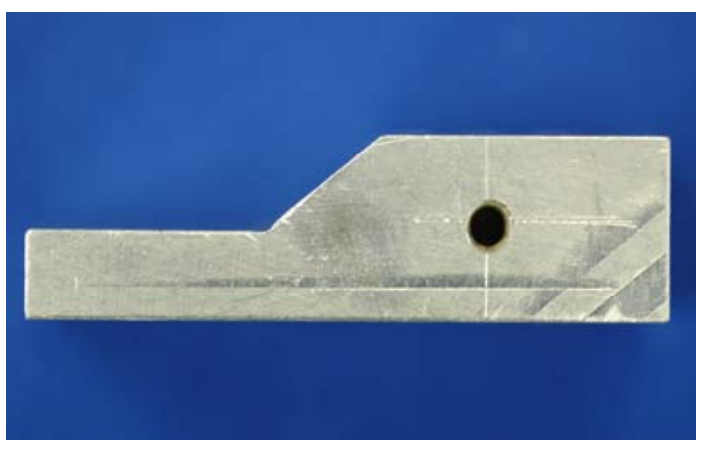

Figura 3 - Vista lateral (lingual) da matriz em aço 


\subsection{Obtenção da matriz de silicone para a confecção das próteses provisórias}

Com o objetivo de padronizar a forma e as dimensões das próteses provisórias, foi feita uma matriz em poli(vinilsiloxano) de uso laboratorial (Poly Pour, GC Lab Technologics Inc, Alsip, IL, USA) que pudesse ser utilizada diretamente sobre os componentes metálicos do tipo UCLA, posicionados e parafusados sobre os análogos já fixados à matriz metálica. Para a confecção dessa matriz de silicone, foi encerada sobre os pilares do tipo UCLA uma prótese parcial fixa de três elementos, dando-Ihe formas coronárias e oclusais de canino (primeiro pilar), primeiro pré-molar (segundo pilar) e segundo pré-molar (terceiro pilar), além da extensão distal do cantilever (simulando um pré-molar com largura mesio distal de 7,0 mm e um molar com largura mesio distal de $14 \mathrm{~mm}$, fazendo um comprimento total do cantilever de $21 \mathrm{~mm}$ ). (Figuras 4 e 5). Essa matriz de silicone apresentou duas partes, uma base e uma caixa superior, para facilitar a inserção das fibras no terço superior nas áreas de conexão e extremo livre, além de orifícios localizados superiormente para injeção e extravasamento da resina acrílica (Figuras 6 a 10). 


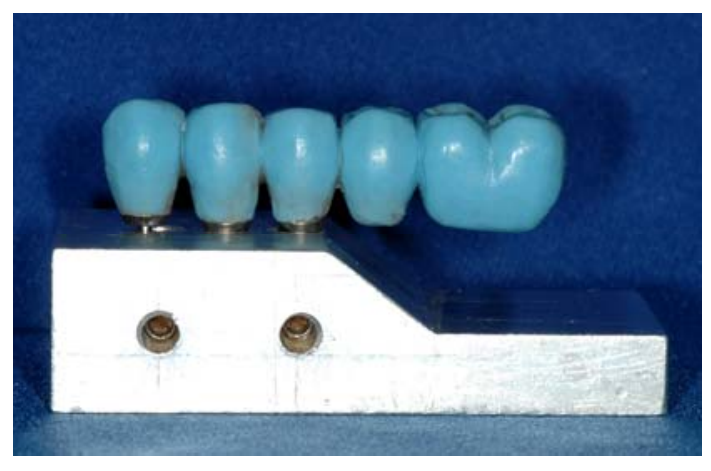

Figura 4 - Vista vestibular do enceramento para obtenção da matriz de silicone

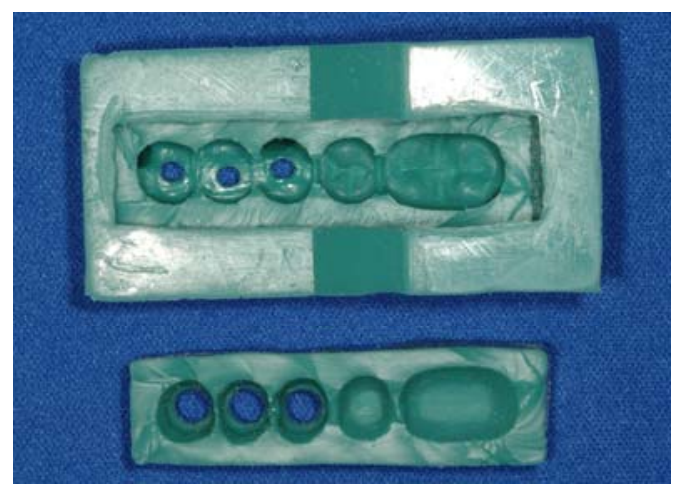

Figura 6 - Vista interior da parte superior e inferior da matriz de silicone

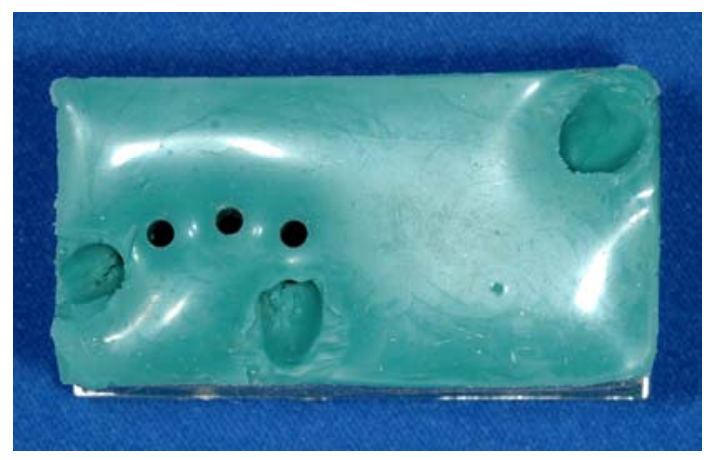

Figura 8 - Parte superior da matriz de silicone

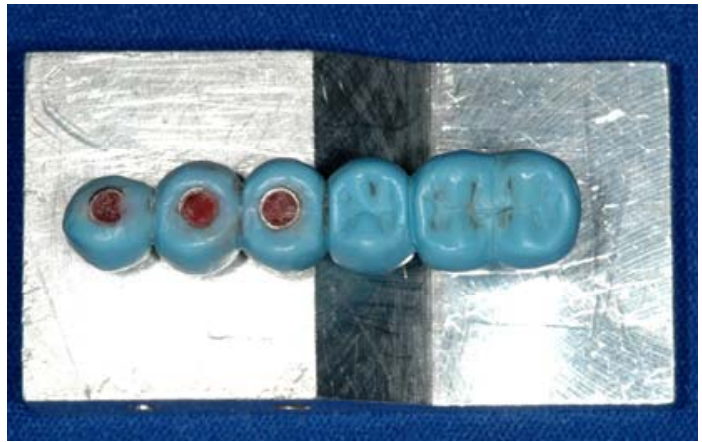

Figura 5 - Vista oclusal do enceramento

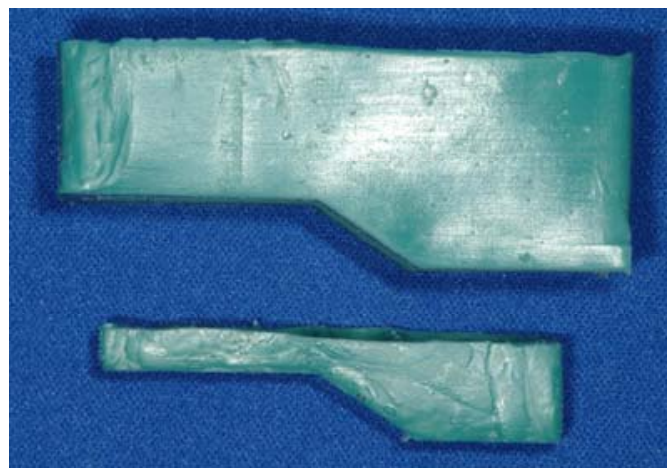

Figura 7 - Vista lateral de matrizes de silicone antes de ser acopladas

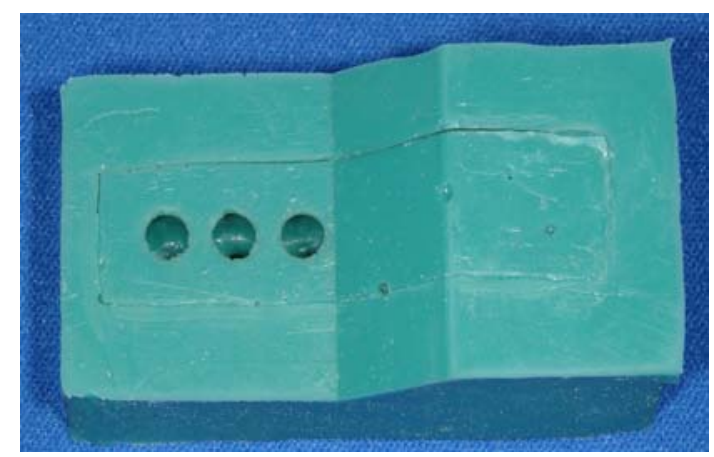

Figura 9 - Parte inferior da matriz de silicone que será articulada com a matriz de aço 


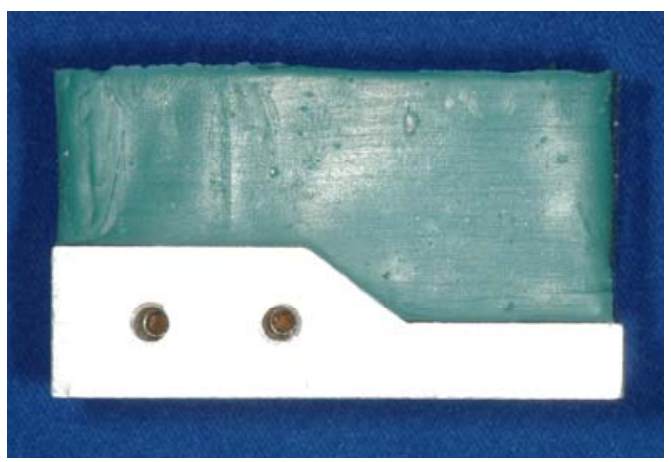

Figura 10 - Articulação da matriz de silicone sobre a matriz de aço

\subsection{Confecção dos espécimes}

Sobre os análogos dos implantes (Análogo 4.1, sem antirotacional, de Titânio, Cód: 101.004, Lote: 658536, Neodent ${ }^{\circledR}$, Implante osteointegrável, JJGC Indústria e Comércio de Matérias Dentários LTDA., Indústria Brasileira) fixados na matriz metálica, foram parafusados (Parafuso Sextavado 4.1 e 4.3 Titânio, Cód.: 116.002, Lote: 700570, Neodent ${ }^{\circledR}$ ) os componentes do tipo UCLA para confecção dos provisórios, (UCLA titânio 4.1, Cód: 118.030, Lote: 659637, Neodent ${ }^{\circledR}$ ) este procedimento foi realizado para todos os espécimes, com e sem reforço (Figura 11).

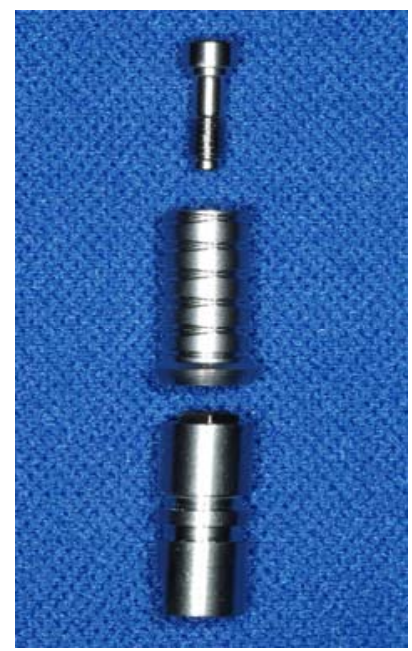

Figura 11 - Análogo, componente protético para confecção do provisório, e parafuso Neodent ${ }^{\circledR}$ 
Todas as próteses provisórias foram preparadas utilizando a resina Dencor ${ }^{\circledR}$ (Artigos Odontológicos Clássico LTDA, São Paulo - SP), cor nº 66. A resina Dencor ${ }^{\circledR}$ é uma resina acrílica PMMA autopolimerizável indicada, segundo os fabricantes, para a execução de restaurações, coroas e facetas, e empregada rotineiramente na confecção direta e indireta de próteses provisórias.

O presente estudo foi constituído por nove grupos de dez espécimes cada um. Para cada comprimento de cantilever, 7, 14 e $21 \mathrm{~mm}$, foram realizados três grupos: um grupo controle, sem a adição de fibras, um grupo reforçado com as fibras de vidro $\left(\right.$ Fibrante $^{\circledR}$ ) e outro com fibras de poli(aramida) $\left(\operatorname{Kevlar}^{\circledR}\right)$. As identificações e características dos reforços utilizados assim como a divisão dos grupos encontram-se especificados na Tabela 1 e 2. As figuras 12 e 13 apresentam os reforços utilizados nos respectivos grupos.

Tabela 1 - Descrição do material de reforço utilizado e divisão dos grupos

\begin{tabular}{|c|c|c|c|c|}
\hline Grupos & Nome/Fabricante & Composição & Medidas & Referência \\
\hline Controle & Sem reforço & - & - & - \\
\hline \multirow[t]{5}{*}{ Fibrante } & Fibrante $^{\circledR}$ & Fibras de vidro & Um feixe de fibras & $N^{0}$ ref.: 490 \\
\hline & Ângelus ${ }^{\circledR}$ - Odonto- & unidirecionais & com $500 \mathrm{~mm}$ de & No lote: 2174 \\
\hline & lógika Ind. Ltda - & impregnadas com & extensão & \\
\hline & Londrina, PR - & glicoldimetacrilato & & \\
\hline & Brasil & & & \\
\hline \multirow[t]{4}{*}{ Kevlar } & & & & \\
\hline & Kevlar ${ }^{\circledR} 49$-- Du & Fibras unidirecionais de & Malha medindo & \\
\hline & Pont $^{\circledR}$, Wilmington, & poli(aramida) sem & $1,0 \times 10^{6} \mathrm{~mm}^{2}$ & $N^{0} 29$ \\
\hline & DE, USA & impregnação & & \\
\hline
\end{tabular}


Tabela 2 - Divisão dos grupos em função dos parâmetros avaliados: comprimento do cantilever e reforço utilizado

\begin{tabular}{|c|c|c|c|}
\hline & CANTILEVER & REFORÇO UTILIZADO & $\begin{array}{c}\mathrm{N}\left(\mathrm{n}^{\circ} . \mathrm{de}\right. \\
\text { espécimes) }\end{array}$ \\
\hline & & Controle - ausência de reforço & 10 \\
\hline & $7 \mathrm{~mm}$ & Fibrante - Fibras de vidro & 10 \\
\hline & & Kevlar - Fibras de Poli(aramida) & 10 \\
\hline \multirow[t]{6}{*}{ GRUPOS } & & Controle - ausência de reforço & 10 \\
\hline & $14 \mathrm{~mm}$ & Fibrante - Fibras de vidro & 10 \\
\hline & & Kevlar - Fibras de Poli(aramida) & 10 \\
\hline & & Controle - ausência de reforço & 10 \\
\hline & $21 \mathrm{~mm}$ & Fibrante - Fibras de vidro & 10 \\
\hline & & Kevlar - Fibras de Poli(aramida) & 10 \\
\hline
\end{tabular}

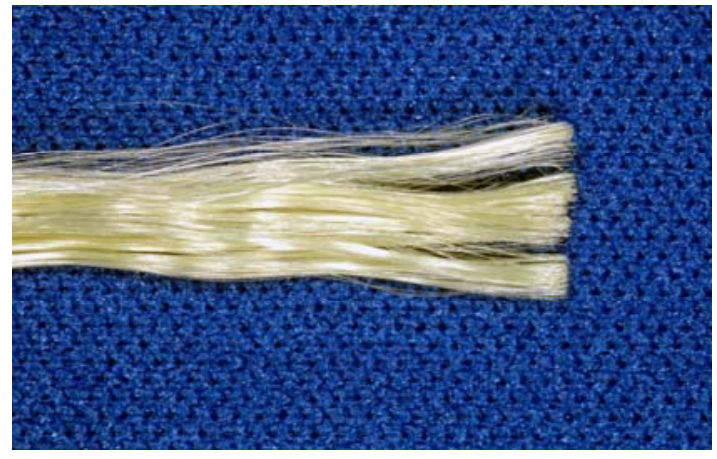

Figura 12 - Detalhe da fibra de poli(aramida) Kevlar ${ }^{\circledR}$ Du Pont ${ }^{\circledR}$

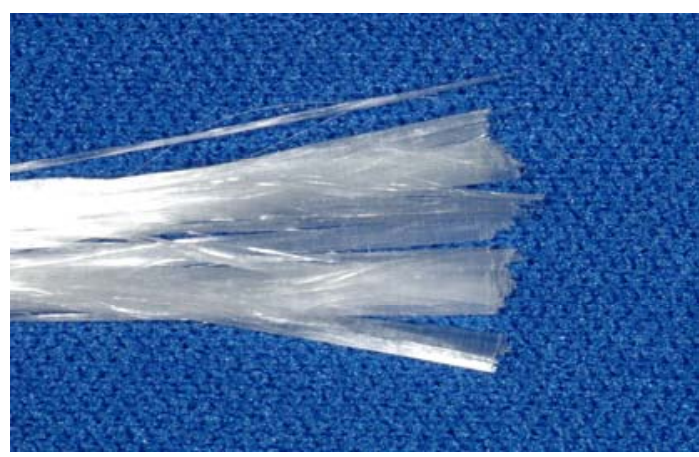

Figura 13 - Detalhe da fibra de vidro Fibrante $₫$ Ângelus $₫$ - Odontológika Ind. Ltda 


\subsection{Confecção dos espécimes sem reforço (Grupo CONTROLE)}

Para confecção dos corpos de prova sem reforço (grupo Controle), o polímero (pó) da resina foi pesado em uma balança com precisão de 0,001 g (Sauter ${ }^{\circledR}$, modelo K1200, Switzerland), enquanto o monômero (líquido) foi aspirado e medido com uma pipeta $\left(\right.$ Pyrobras $^{\circledR}$ ) № 7079 , com capacidade de $5 \mathrm{ml}$, graduada em intervalos de 0,1 ml. (Figura 31)

$\mathrm{Na}$ mistura, foram utilizados 4,0 $\mathrm{g}$ de polímero e 2,7 $\mathrm{ml}$ de monômero, equivalente à proporção em volume de 3:1, indicada pelo fabricante, sendo que a mistura não foi utilizada em sua totalidade na confecção do corpo de prova, havendo sobras. O líquido (monômero) foi vertido em um pote Dappen e sobre ele foi dispensado o pó (polímero). O pó e o líquido foram misturados lentamente por aproximadamente cinco segundos, com o auxílio de uma espátula $\mathrm{n}^{07}$. Esperou-se a saturação do conjunto, durante cerca de 40 segundos, enquanto o mesmo permanecia no interior do pote Dappen coberto com uma placa de vidro medindo $5 \mathrm{~cm}$ de largura por $5 \mathrm{~cm}$ de comprimento.

A resina foi colocada em uma seringa plástica de $10 \mathrm{ml}$ e foi injetada no interior da matriz de silicone. Esta se encontrava posicionada sobre a matriz metálica e envolvia os componentes protéticos tipo UCLA. A resina foi injetada por um dos orifícios até que extravasasse pelo outro. Previamente a este procedimento, uma pequena porção de material de moldagem a base de poliéter (3M ESPE Impregum ${ }^{\mathrm{TM}}$ Soft) foi colocado no interior do componente protético 
provisório, selando-o desta maneira e evitando o contato direto do parafuso com a resina (Figura 14 e 15).

O excesso de resina extravasado pelos orifícios superiores da matriz foi removido com uma lâmina de bisturi $n^{0} 11$. A manipulação e a inserção da resina foram realizadas em laboratório com temperatura e umidade relativa do ar controladas, em $22^{\circ} \mathrm{C}$ e $45 \%$, respectivamente.

As partes da matriz foram acopladas com ajuda de uma pequena placa de vidro colocada sobre a matriz de silicone. Sobre este conjunto foi colocado um frasco de plástico contendo no seu interior chumbo (500 g) para que as mesmas mantivessem o máximo de contato possível. As partes da matriz possuíam marcas coincidentes para auxiliar na verificação visual da obtenção do ajuste entre as mesmas (Figura 20).

O conjunto formado pelas matrizes, contendo em seu interior a resina ainda plástica, junto com a placa de vidro e o chumbo colocado no interior do frasco plástico, foi imerso em água, em um recipiente plástico, e levado ao interior de uma estufa por dez minutos (Fanem, mod. 315 - SE, SP, Brasil) a $37^{\circ}$ C. Após a polimerização inicial, aproximadamente 10 minutos, o espécime foi removido cuidadosamente da matriz de silicone e imediatamente desparafusado. Em seguida, foi armazenado novamente em água, a $37^{\circ} \mathrm{C} \pm 0,1$, por 15 dias. Posteriormente, os espécimes foram medidos e recortados nas medidas estabelecidas para as extensões do cantilever $(7,14,21 \mathrm{~mm})$. O acabamento foi dado um dia antes do ensaio com brocas multilaminadas de carbide de tungstênio (Código H79 E. 
104.050, Komet-Brasseler, Germany) e um disco de silicone abrasivo (Código 9627.900.220, Komet-Brasseler, Germany).

Após o acabamento, as áreas de conexão foram novamente medidas com o auxílio de um paquímetro digital Starrett 727 (Código 727 - 6/150, Starrett Ind. e Com. Ltda, São Paulo, Brasil) confirmando suas medidas em altura e largura, de 5,5 \pm 0,1 e 5,0 $\pm 0,1 \mathrm{~mm}$, respectivamente, em ambos os conectores mesial e distal (Figuras 25 a 28). Após o acabamento, os espécimes permaneceram armazenados em água, a $37^{\circ} \mathrm{C}$, até o momento do ensaio mecânico.

\subsection{Confecção dos espécimes com reforço}

Os espécimes reforçados foram confeccionados de forma similar aos sem reforço, com a resina tendo sido igualmente proporcionada e misturada.

As fibras Fibrante ${ }^{\circledR}$ e Kevlar $^{\circledR}$ foram dispostas em longos feixes para possibilitar a padronização da quantidade de fibras. Os feixes, de aproximadamente $50 \mathrm{~mm}$ de comprimento, foram desfiados até que apresentassem peso de 0,053 g, 0,066 g e 0,08 g cada um, para as próteses com distancia de cantilever de 7, 14 e $21 \mathrm{~mm}$ respectivamente. As fibras Fibrante ${ }^{\circledR}$ são comercializadas apresentando dimensões de $50 \mathrm{~mm}$ de comprimento, por isso, utilizou-se essa extensão. As fibras foram pesadas em uma balança modelo 2662 
fabricada por Sartorius - Werke AG (Göttingen, Alemanha), com capacidade máxima de $200 \mathrm{~g}$ e acuidade de 0,0001g (Figura 32).

As porções de fibras, que seriam utilizadas como reforços dos espécimes, foram imersas no monômero MMA da resina Dencor ${ }^{\circledR}$, durante cinco minutos. Após a remoção do excesso de monômero com lenços de papel, as fibras foram proporcionadas equitativamente em duas partes e fixadas aos componentes protéticos, posicionados sobre os análogos fixados à matriz metálica, por meio de um adesivo à base de cianocrilato (SuperBonder, Loctite-Henkel Ltda., São Paulo, Brasil). As fibras foram dispostas de forma que as mesmas circundassem a 2,0 mm abaixo da superfície oclusal dos componentes e na região do conector do cantilever. As mesmas foram cruzadas (formando um " $x$ ") entre os conectores e estendidas no interior do cantilever, de forma que ficassem totalmente imersas na resina acrílica (Figura 14 a 16).

A inserção da resina nos grupos com reforço foi realizada em duas fases: 1) a resina foi aplicada com o auxílio de uma seringa no interior da matriz de silicone e sobre o reforço, prevenindo, assim, a incorporação de bolhas de ar. 2) em seguida, a parte superior da matriz de silicone foi posicionada e o restante da resina foi injetado através de um dos orifícios até que ocorresse o seu extravasamento pelos outros orifícios. Após esse procedimento, realizou-se a mesma seqüência de acoplagem das matrizes, polimerização a $37^{\circ} \mathrm{C}$ em estufa, armazenamento em água, a $37^{\circ} \mathrm{C} \pm 0,1$, por 15 dias. Posteriormente, a medição, recorte e acabamento dos espécimes, para a obtenção do comprimento do cantilever já estabelecido (7,14,21 mm), antes do ensaio mecânico ( Figura 17 a 30). 


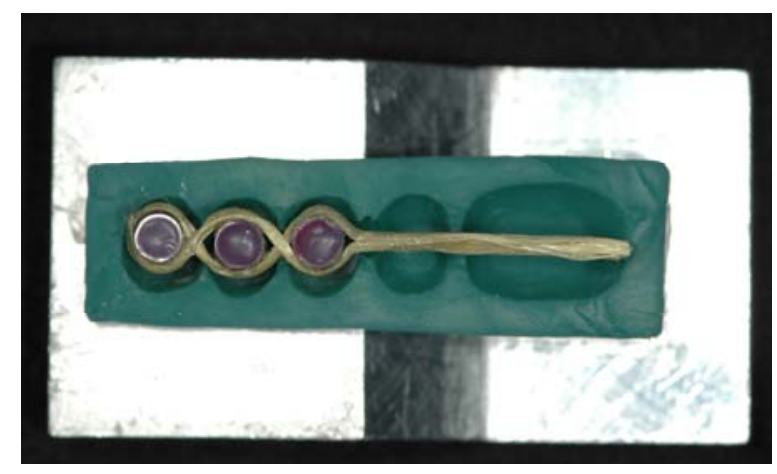

Figura 14 - Vista oclusal do posicionamento das fibras do grupo Kevlar

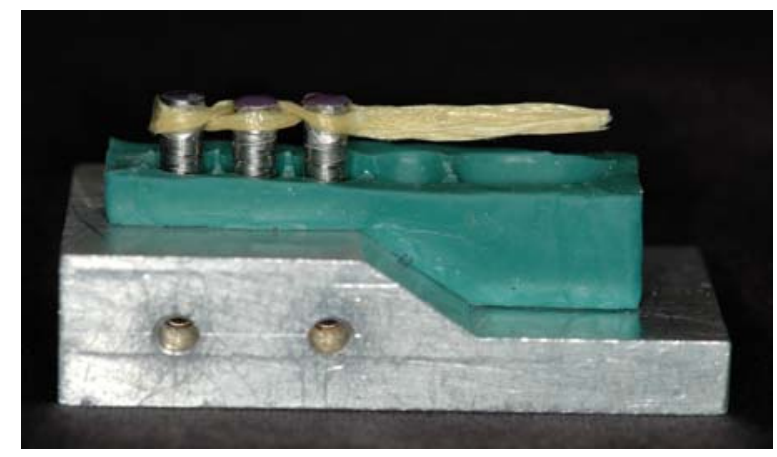

Figura 16 - Vista frontal mostrando o posicionamento das fibras sobre as matrizes de silicone e metálica

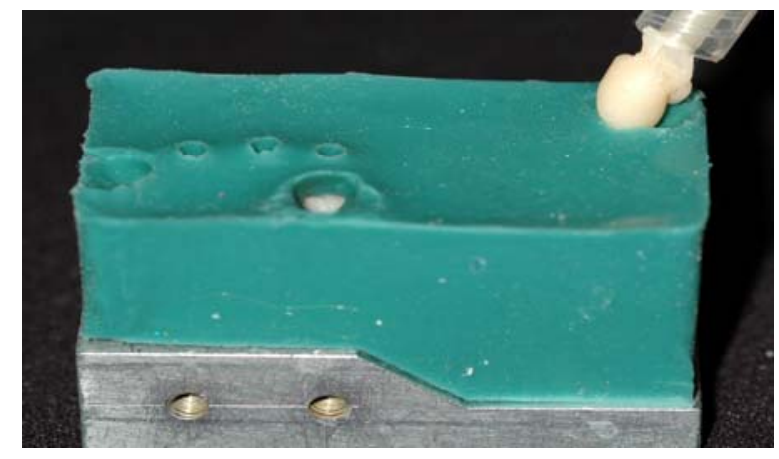

Figura 18 - Injeção da resina através do orifício na parte superior da matriz de silicone até o seu extravasamento

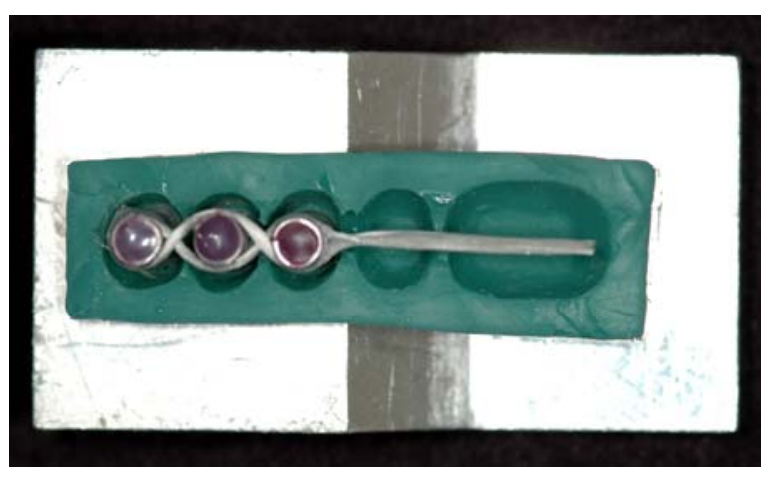

Figura 15 - Vista oclusal do posicionamento das fibras do grupo Fibrante

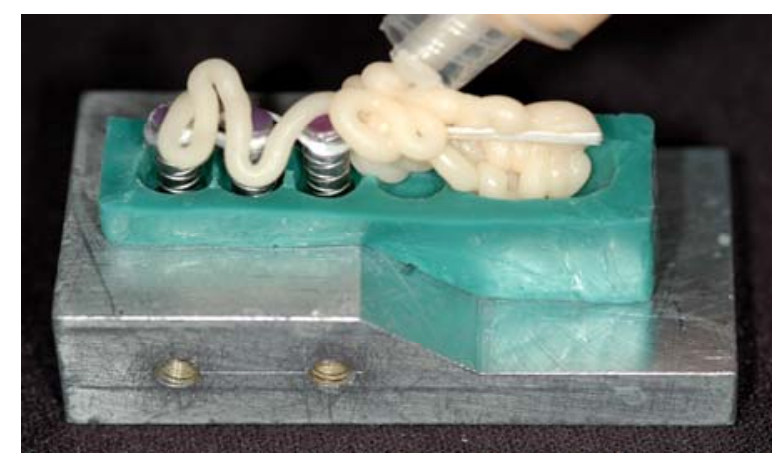

Figura 17 - Injeção da resina na base da matriz de silicone e sobre as fibras previamente posicionadas

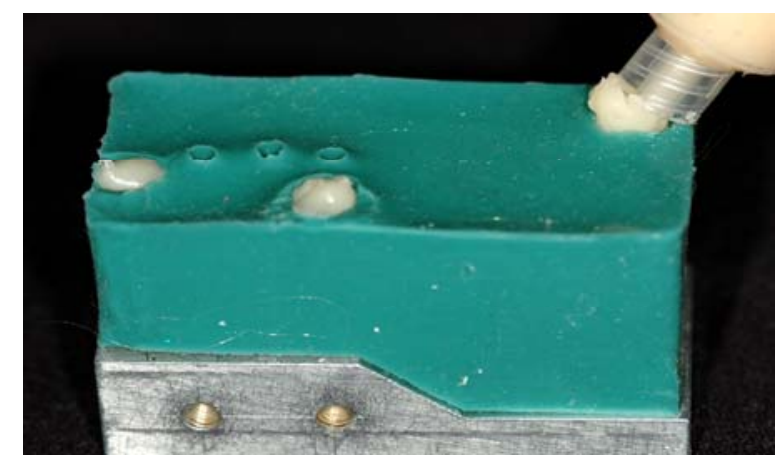

Figura 19 - Extravasamento da resina pelos orifícios superiores da matriz de silicone 


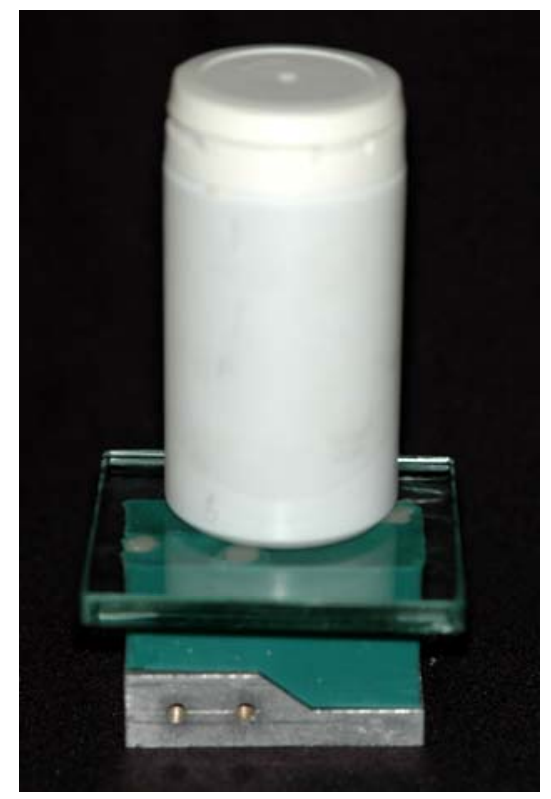

Figura 20 - Disposição das matrizes após a completa inserção da resina, com a apreensão de suas partes através de uma placa de vidro e um frasco contendo $500 \mathrm{~g}$ de chumbo

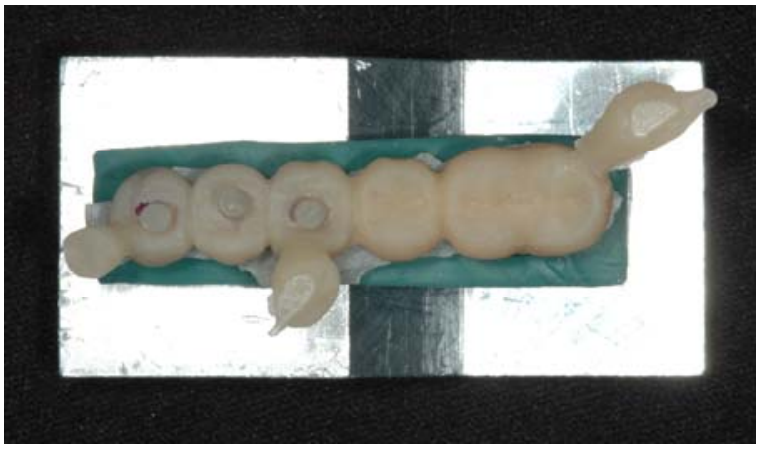

Figura 21 - Vista oclusal do espécime, após a polimerização da resina, simulando prótese parcial fixa provisória com um cantilever de $21 \mathrm{~mm}$ de comprimento

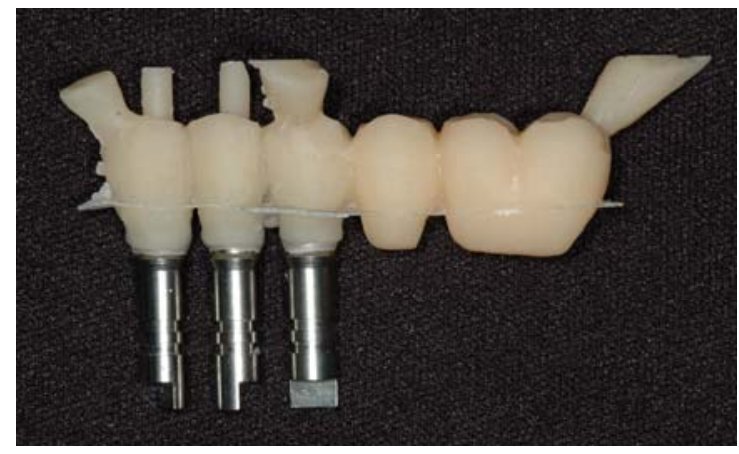

Figura 22 - Vista frontal do espécime após a remoção das matrizes utilizadas para a sua confecção 


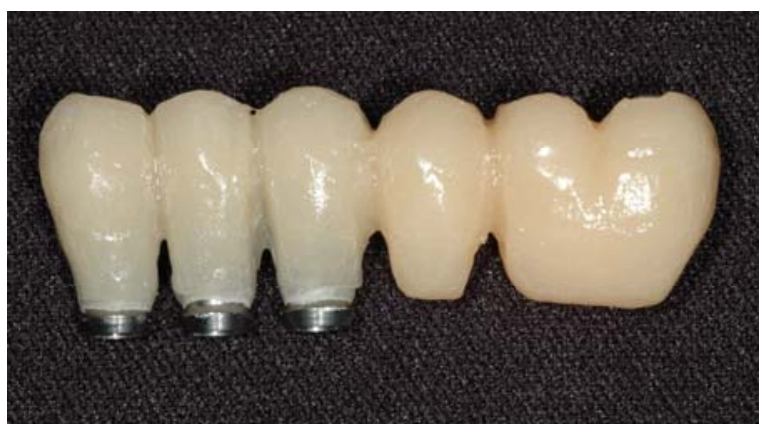

Figura 23 - Vista frontal do espécime após o acabamento com a remoção dos excessos de resina

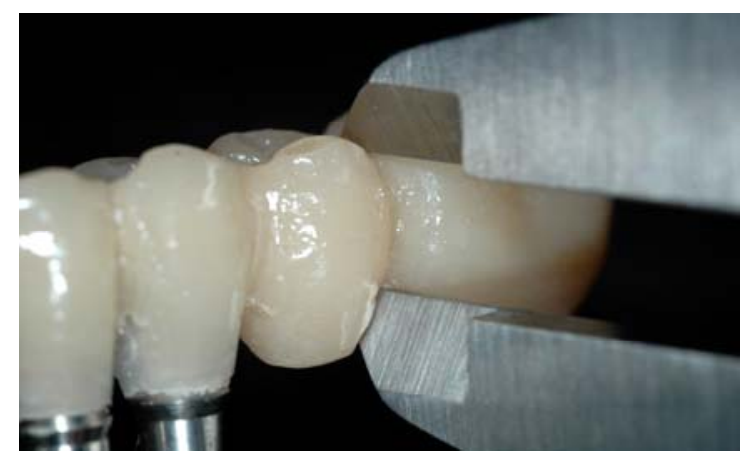

Figura 25 - Mensuração do espécime após o acabamento: altura do conector

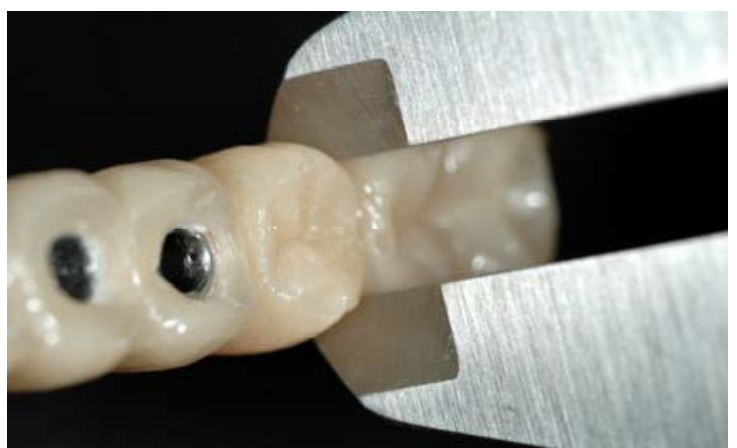

Figura 27 - Mensuração do espécime após o acabamento: largura do conector

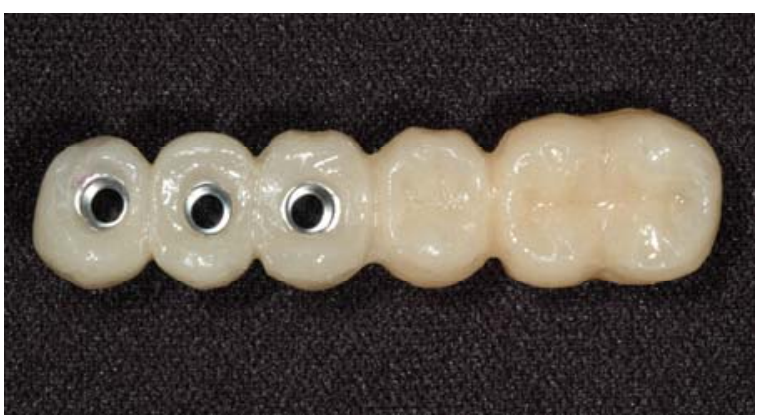

Figura 24 - Vista oclusal do espécime após o acabamento

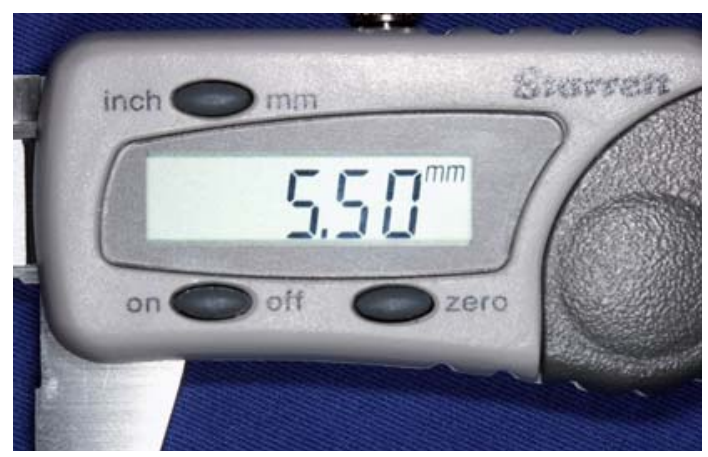

Figura 26 - Paquímetro digital padronizando a altura do conector

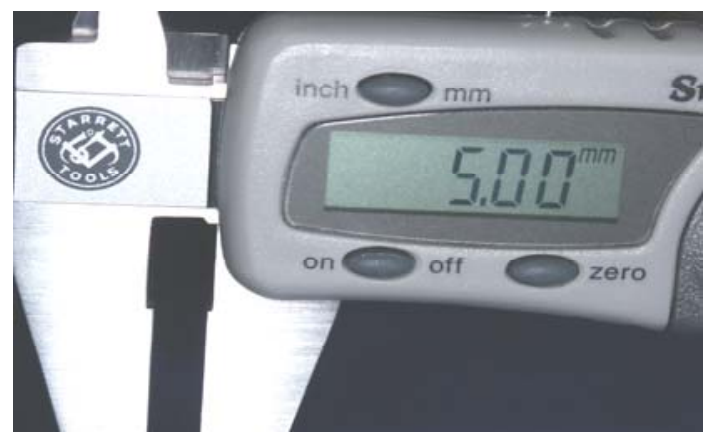

Figura 28 - Paquímetro digital padronizando a largura do conector 


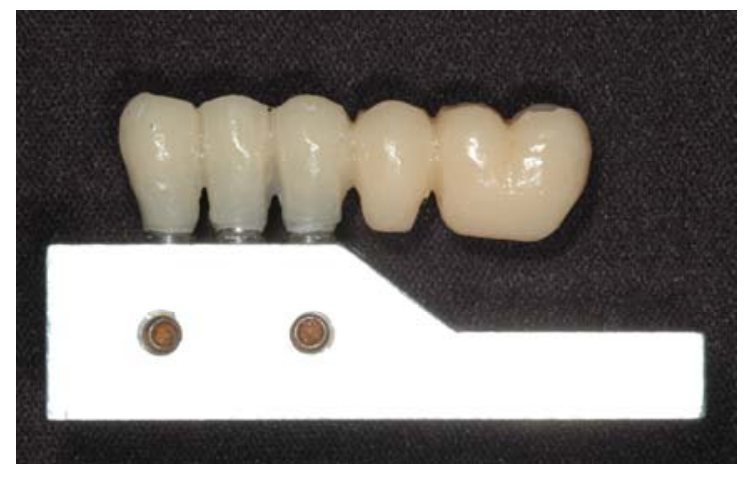

Figura 29 - Vista frontal do espécime colocado na matriz de aço, pronto para ser submetido ao teste de resistência à fratura

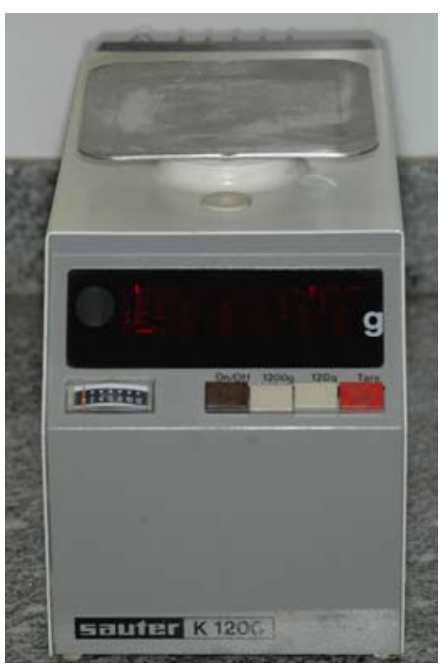

Figura 31 - Balança com precisão de $0,001 \mathrm{~g}$ (Sauter $^{\mathrm{\theta}}$, model K1200, Switzerland) utilizada para a mensuração da resina

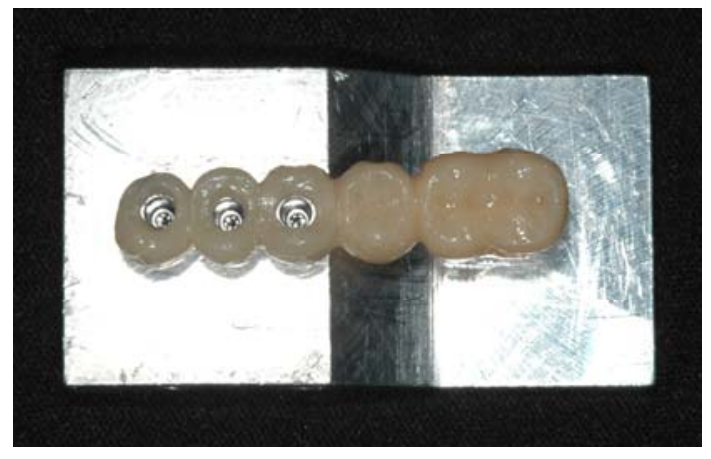

Figura 30 - Vista oclusal do espécime colocado na matriz de aço

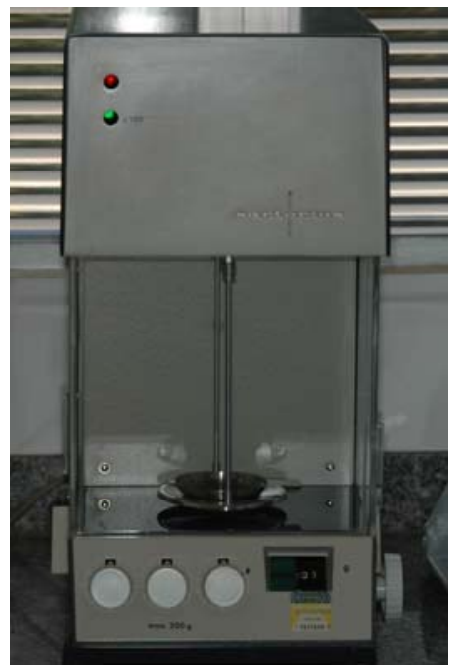

Figura 32 - Balança modelo 2662 fabricada por Sartorius-Werke AG (Göttingen, Alemanha), com capacidade máxima de $200 \mathrm{~g}$ e acuidade de $0,0001 \mathrm{~g}$ utilizada para a mensuração das fibras 


\subsection{Ensaio mecânico}

Os espécimes, simulando próteses provisórias com cantilever distal de 7, 14 e $21 \mathrm{~mm}$, foram fixados sobre a matriz metálica por meio dos mesmos análogos e parafusos de titânio utilizados em sua confecção. Dessa maneira, nenhum dos análogos e parafusos de titânio foram reutilizados, somandose três análogos e três parafusos de titânio para cada corpo de prova. Para a fixação dos provisórios aos seus respectivos análogos, a cada parafuso foi dado o torque de $32 \mathrm{~N} / \mathrm{cm}$, utilizando-se um torquímetro manual de marca comercial Neodent ${ }^{\circledR}$ - Brasil. (Figura 33 e 34).

O ensaio mecânico para registro da resistência à fratura foi realizado em uma máquina universal de ensaios Kratos ${ }^{\circledR}$ (Kratos - Dinamômetros Ltda. São Paulo - SP). A máquina de ensaio esta ilustrada na figura 35.

Após a fixação do espécime à matriz metálica, uma ponta metálica, com $\varnothing 8,0 \mathrm{~mm}$ em aço temperado, foi posicionada e ajustada sobre um ponto localizado a $1,0 \mathrm{~mm}$ da extremidade distal da crista marginal do cantilever, determinado previamente no enceramento. O teste foi executado com o auxílio de uma célula de carga de 500 kgf, sendo que a máquina foi configurada para exercer uma pré-carga inicial de 0,060 kgf. A força foi aplicada pelo cabeçote a uma velocidade constante de $1,0 \mathrm{~mm} / \mathrm{min}$. Os espécimes foram submetidos à carga compressiva até a fratura. O valor de carga máximo, em kgf, obtido em cada 
espécime, foi registrado e impresso juntamente com o seu respectivo gráfico, por meio do programa de computador próprio da $\operatorname{Kratos}^{\circledR}$ (Figura 36 a 38). 


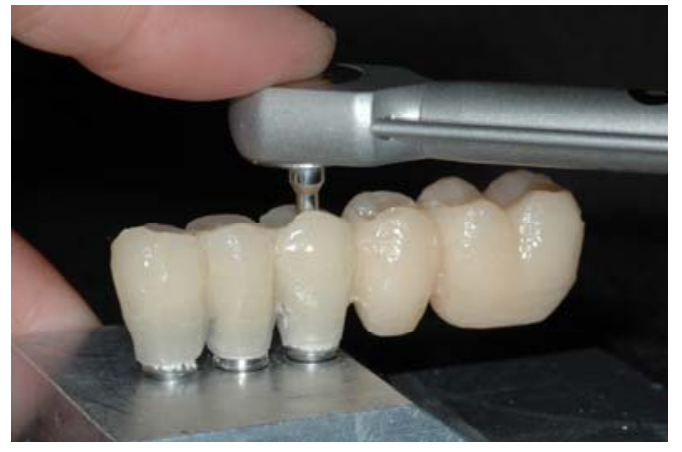

Figura 33 - Fixação dos provisórios aos seus respectivos análogos. Os parafusos de fixação receberam torque de $32 \mathrm{~N} / \mathrm{cm}$

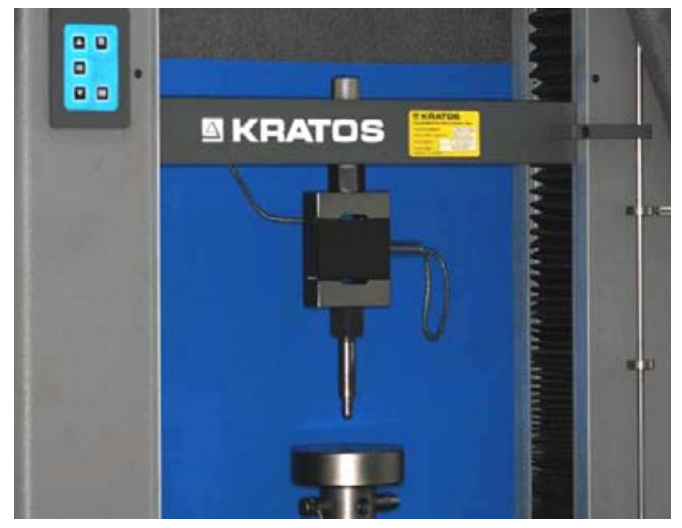

Figura 35 - Máquina universal de ensaios Kratos $^{\circledR} \quad$ (Kratos Dinamômetros Ltda. São Paulo - SP), utilizada para os ensaios de resistência à fratura

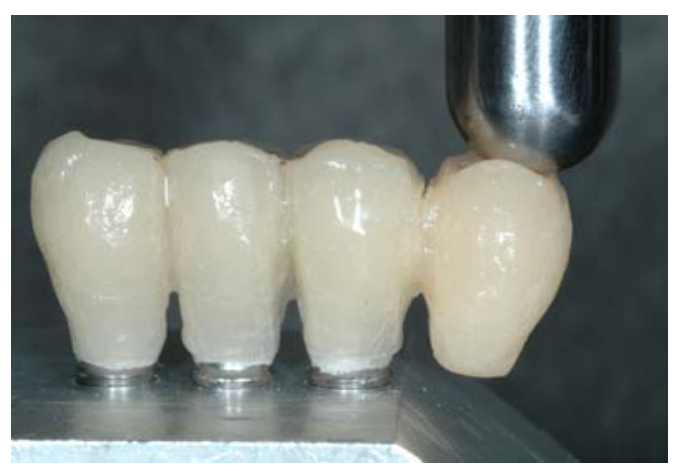

Figura 37 - Vista frontal mostrando a fratura na região do conector mesial, quando a carga foi exercida (cantilever $7 \mathrm{~mm}$ )

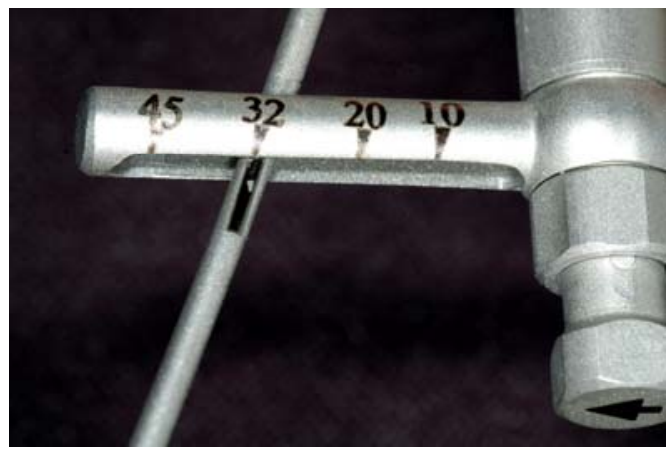

Figura 34 - Torque de $32 \mathrm{~N} / \mathrm{cm}$ realizado com torquímetro Neodent ${ }^{\circledR}$ Brasil

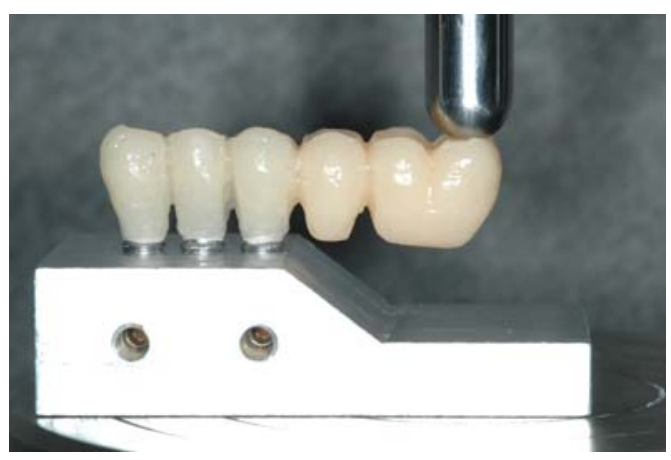

Figura 36 - Espécime fixado sobre a matriz de teste, com a esfera posicionada a $1,0 \quad \mathrm{~mm} \quad \mathrm{da}$ extremidade distal da crista marginal do cantilever, para exercer a carga durante 0 ensaio de resistência à fratura

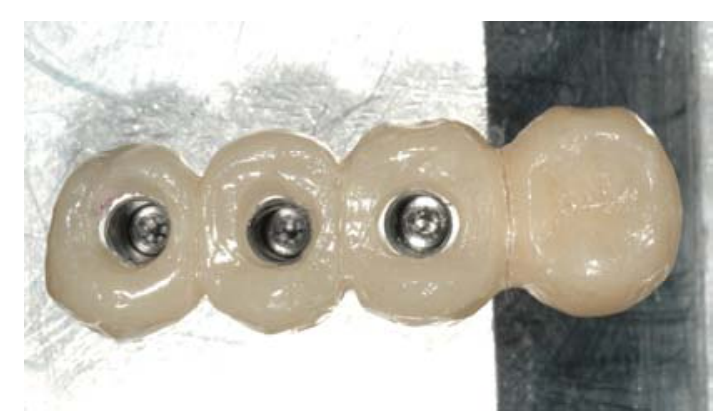

Figura 38 - Vista oclusal mostrando a fratura na região do conector mesial, quando a carga foi exercida (cantilever $7 \mathrm{~mm}$ ) 


\subsection{Cálculo da resistência à fratura}

O valor de resistência à fratura, em kgf, obtido em cada espécime foi multiplicado pelo valor aproximado da força da gravidade, ou seja 9,807, para se obter o resultado em Newton (N).

\subsection{Classificação das fraturas}

Após o ensaio, cada corpo de prova foi avaliado com auxílio de uma lupa com aumento de quatro vezes (Bio-Art Equip. Odont. Ltda. São Carlos, SP - Brasil), para a classificação das fraturas. Realizou-se a seguinte classificação dos espécimes, de acordo com o modo de fratura (Figuras 39 a 41):

a) Fratura Parcial, aquela que se estendeu à interface reforço-resina, ou às suas proximidades;

b) Fratura Total Não Separada, aquela que se propagou para além do reforço e dividiu o espécime em duas metades, mantidas unidas pelo reforço não fraturado; e

c) Fratura Total Separada, aquela que fraturou completamente o espécime, separando-o em duas metades, sendo que nas amostras reforçadas o material utilizado como reforço também sofreu fratura. 


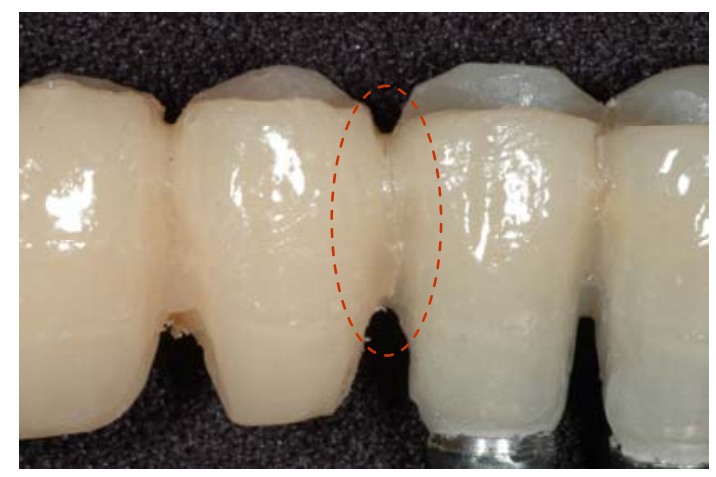

Figura 39 - Detalhe da fratura do tipo Parcial apresentada pelos espécimes do grupo Fibrante

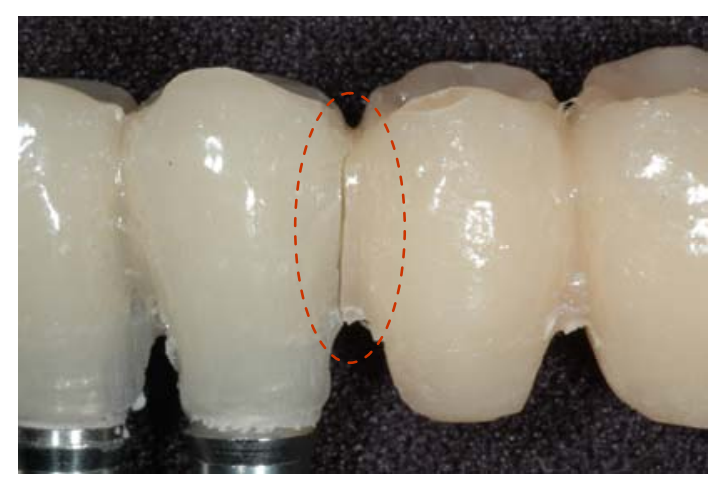

Figura 40 - Detalhe da fratura do tipo Parcial apresentada pelos espécimes do grupo Kevlar

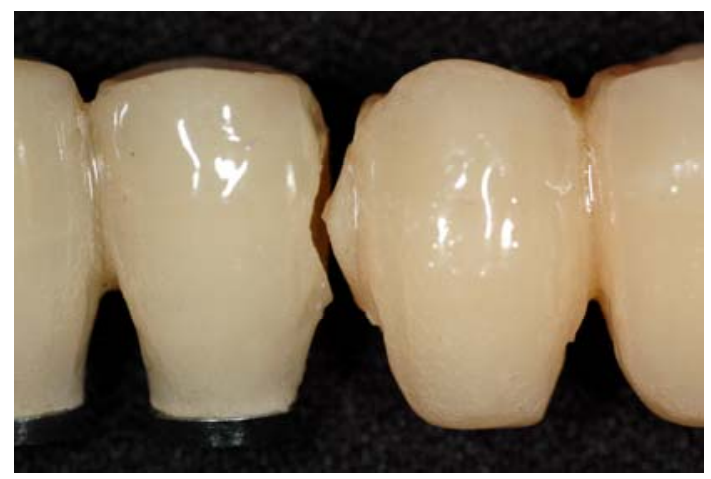

Figura 41 - Detalhe da fratura do tipo Total Separada apresentada pelos espécimes do grupo controle (sem reforço) 


\subsection{Análise estatística}

Todos os dados gerados a partir do ensaio mecânico de resistência a fratura, foram submetidos ao teste de Barlett, com significância de 5\%, para constatar a homogeneidade da amostra. Para verificar a normalidade dos dados, utilizou-se o teste de Kolmogorov-Smirnov, com significância de 5\%. Uma vez constatadas a homogeneidade e a normalidade dos dados, realizou-se o teste paramétrico de Análise de Variância (ANOVA), com significância de 5\%, para verificação da existência de diferença estatística entre os grupos, quanto aos parâmetros avaliados. Após o teste ANOVA, realizou-se o Teste de Tukey para identificar quais grupos apresentaram médias significantemente diferentes entre si.

A análise das fraturas dos espécimes foi apresentada em valores percentuais representativos da ocorrência de cada tipo de fratura em cada grupo. 
5 RESULTADOS 


\section{RESULTADOS}

Os valores individuais de resistência à fratura (em Kgf e em N) e modo de fratura dos espécimes de todos os grupos, reforçados ou não, estão exibidas no anexo.

As médias da resistência à fratura e o desvio padrão de cada grupo se encontram na Tabela 3. A figura 42 ilustra os resultados das diferenças entre as médias dos valores de resistência à fratura dos diferentes grupos.

Tabela 3 - Valores das médias e desvio padrão da resistência à fratura dos grupos

\begin{tabular}{lccc}
\hline \multicolumn{1}{c}{ Grupo } & Média & Desvio padrão & $\begin{array}{c}\mathbf{n}^{\mathbf{0}} \text {. de } \\
\text { espécimes }\end{array}$ \\
\hline Controle $7 \mathrm{~mm}$ & 28,07 & 5,47 & 10 \\
Controle $14 \mathrm{~mm}$ & 8,27 & 1,83 & 10 \\
Controle $21 \mathrm{~mm}$ & 6,39 & 0,96 & 10 \\
Fibra Kevlar 7 mm & 31,89 & 3,03 & 10 \\
Fibra Kevlar 14 mm & 9,18 & 2,02 & 10 \\
Fibra Kevlar 21 mm & 5,16 & 0,73 & 10 \\
Fibra Fibrante $7 \mathrm{~mm}$ & 30,90 & 4,45 & 10 \\
Fibra Fibrante $14 \mathrm{~mm}$ & 9,31 & 2,51 & 10 \\
\hline Fibra Fibrante $21 \mathrm{~mm}$ & 6,86 & 1,80 & \\
\hline
\end{tabular}




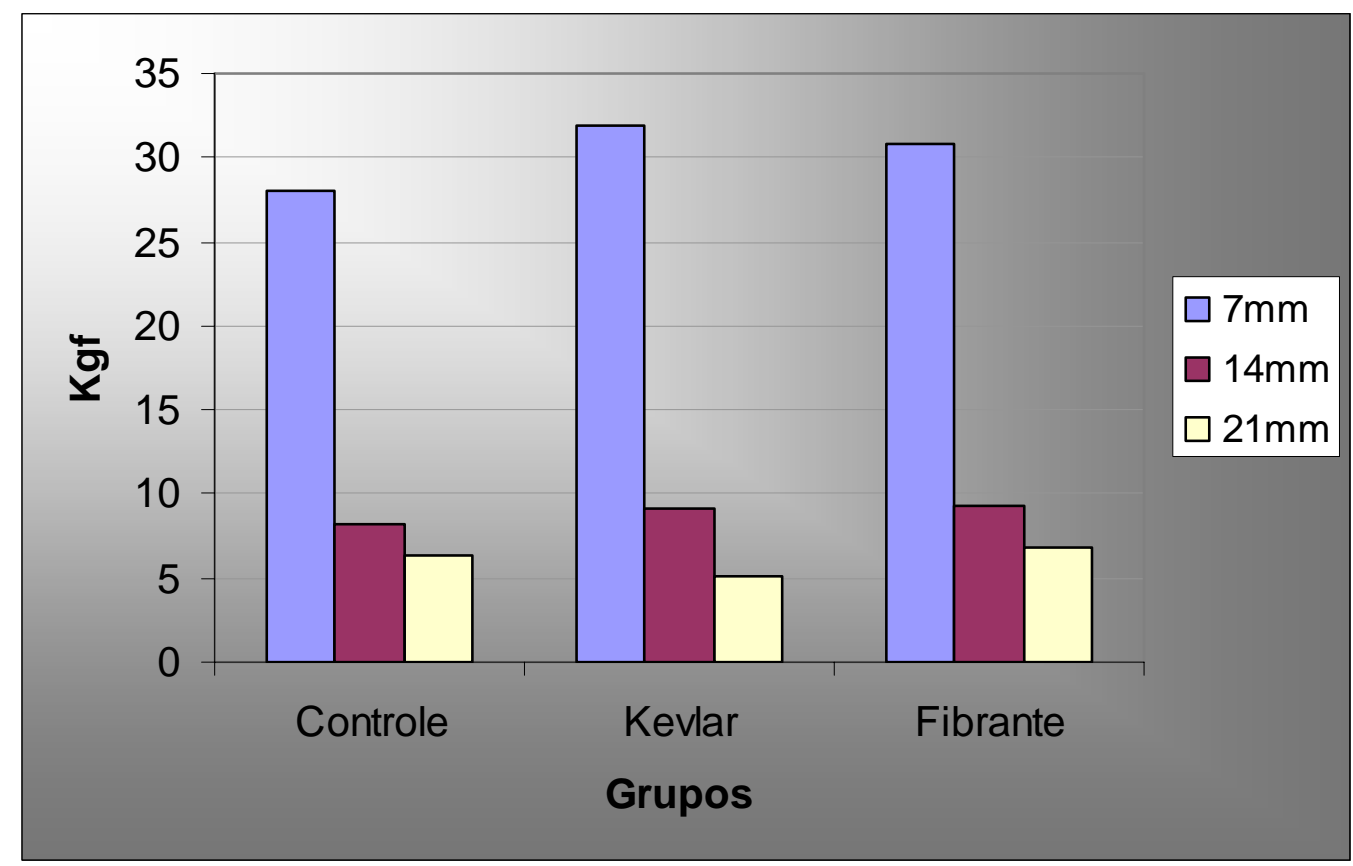

Figura 42 - Médias dos valores de resistência à fratura (Kgf) dos grupos estudados

Para verificar se os dados passavam pelos critérios de homocedasticidade (homogeneidade de variâncias) e de distribuição normal, antes de se realizar o teste paramétrico de Análise de Variância (ANOVA), foi aplicado o teste de Bartlett, para verificar a homogeneidade de variâncias entre os grupos, e o teste de Kolmogorov-Smirnov para verificar se os dados possuíam distribuição normal. O teste de Kolmogorov-Smirnov não mostrou diferença significante da distribuição normal enquanto teste de Bartlett demonstrou haver diferença estatisticamente significante entre as variâncias dos grupos $(p<0,001)$. Para corrigir as diferenças entre as variâncias, os dados foram transformados pela função raiz cúbica e confirmado pelo teste de Bartlett não havendo então diferença significativa entre as variâncias $(p=0,106)$. Após a transformação foi então executado o teste de ANOVA cujo resultado está ilustrado na tabela 4. 
Tabela 4 - Análise de variância (ANOVA) dos resultados da resistência à fratura dos espécimes

\begin{tabular}{|c|c|c|c|c|c|c|c|}
\hline & Df & MS & Df & MS & & & \\
\hline & Efeito & Efeito & Erro & Erro & $F$ & $\mathbf{P}$ & Interpretação \\
\hline $\begin{array}{l}\text { Tipo de } \\
\text { reforço }\end{array}$ & 2 & 0,03805 & 81 & 0,022659 & 1,679467 & 0,192901 & $\begin{array}{c}\text { Não } \\
\text { significante }\end{array}$ \\
\hline $\begin{array}{c}\text { Comprimento } \\
\text { cantilever }\end{array}$ & 2 & 14,07065 & 81 & 0,022659 & 620,9702 & 0 & Significante \\
\hline Interação & 4 & 0,052225 & 81 & 0,022659 & 2,30482 & 0,065293 & $\begin{array}{c}\text { Não } \\
\text { significante }\end{array}$ \\
\hline
\end{tabular}

$\mathrm{Df}=$ grau de liberdade; $\mathrm{MS}=$ Quadrado médio; $\mathrm{F}=$ distribuição estatística de análisis de variância; $\mathrm{P}=$ probabilidade.

O teste de ANOVA mostrou haver diferença estatisticamente significante somente devido ao comprimento do cantilever. Para as comparações individuais foi feito o teste de Tukey, com significância de 0,05 (5\%), os resultados estão exibidos na tabela 5.

Tabela 5 - Comparações individuais obtidas através do Teste de Tukey, com nível de significância de 0.05

\begin{tabular}{cc}
\hline Comparação & $\mathbf{p}$ \\
\hline $7 \mathrm{~mm} \times 14 \mathrm{~mm}$ & $<0,001^{\star}$ \\
$7 \mathrm{~mm} \times 21 \mathrm{~mm}$ & $<0,001^{\star}$ \\
$14 \mathrm{~mm} \times 21 \mathrm{~mm}$ & $<0,001^{\star}$ \\
\hline
\end{tabular}

* diferença estatisticamente significante $(p<0,05)$ 
Os resultados dos tipos de fraturas apresentados pelos espécimes, após o ensaio de resistência à fratura, estão mostrados na tabela 6.

Tabela 6 - Ocorrência, em porcentagem, do modo de fratura apresentado pelos grupos

\begin{tabular}{cccc}
\hline Tipo & $\begin{array}{c}\text { Grupo Controle } \\
(\mathbf{n}=\mathbf{3 0})\end{array}$ & $\begin{array}{c}\text { Grupo Kevlar } \\
(\mathbf{n}=\mathbf{3 0})\end{array}$ & $\begin{array}{c}\text { Grupo Fibrante } \\
(\mathbf{n}=\mathbf{3 0})\end{array}$ \\
\hline Parcial & $0 \%$ & $100 \%$ & $100 \%$ \\
Total não separada & $0 \%$ & $0 \%$ & $0 \%$ \\
Total separada & $100 \%$ & $0 \%$ & $0 \%$ \\
\hline
\end{tabular}

Teste do qui-quadrado $p<0,001$ significante 
6 DISCUSSÃO 


\section{DISCUSSÃO}

De acordo com Burns e colaboradores $(2003)^{10}$, o ajuste e a perfeição na confecção, instalação e manutenção das próteses provisórias são contestados por alguns profissionais que se opõem ao seu refinamento pela natureza provisória dessas restaurações e, especialmente pelo tempo requerido para produzir uma restauração provisória ótima. A exclusão ou negligência em relação à construção das próteses provisórias, porém pode ser a diferença entre o sucesso e a falha do tratamento.

Quando o tratamento reabilitador é realizado através de implantes osseointegrados, a utilização de restaurações provisórias se faz necessária pela necessidade de um direcionamento estético da gengiva e a exposição progressiva de implantes à carga funcional ${ }^{12}$. Os provisórios podem servir para comprovar a osseointegração antes da realização da prótese definitiva.

Um dos materiais empregados, rotineiramente, para a confecção das próteses provisórias é a resina acrílica poli(metilmetacrilato) (PMMA), autopolimerizável. Esta resina apresenta características que sustentam a popularidade de seu uso, tais como: translucidez; facilidade de ajustes, reembasamentos, reparos, manipulação; e baixo custo relativo.

Diversos autores defendem que os polímeros à base de PMMA utilizados para a confecção de próteses provisórias apresentam resistência à fratura diminuída sob a influência de cargas oclusais. Muitos deles propõem a 


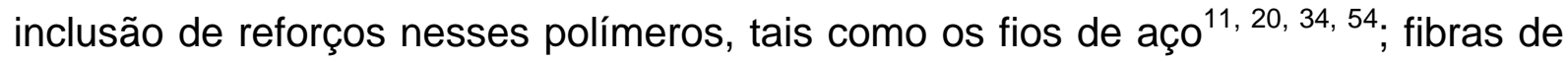

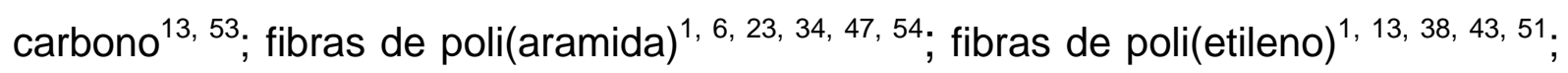
fibras de vidro ${ }^{1}, 4,23,24,25,32,45,47,52,53,54,56$; fibras de sílica ${ }^{56}$; fibras de alumínio ${ }^{17}$; bandas ortodônticas ${ }^{20}$, e fibras de nylon $^{23}$ com a finalidade de aumentar a sua resistência mecânica.

O presente estudo utilizou corpos de prova em forma de próteses provisórias, semelhantes à realidade clínica, apresentando conectores de área transversal aproximada de $27,5 \mathrm{~mm}^{2}$ (5,5 mm de altura x 5,0 mm largura). Foram confeccionados espécimes de três diferentes comprimentos do cantilever (7, 14 e $21 \mathrm{~mm})$.

Neste trabalho utilizamos uma resina PMMA autopolimerizável, indicada para confecção direta e indireta de próteses provisórias, denominada comercialmente Dencor® (Artigos Odontológicos Clássico LTDA, São Paulo - SP). O material de reforço utilizado neste estudo, fibras de vidro e fibras de

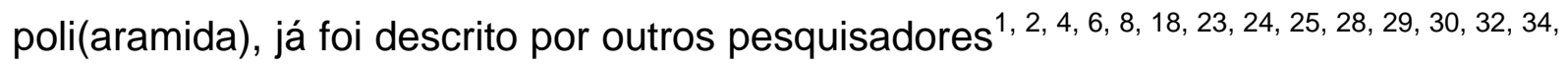
$42,45,47,48,49,50,52,53,54,55,56$, mas ainda não foram avaliados quando utilizados em próteses provisórias sobre implantes com extensões em cantilever.

Muitos detalhes da composição da fibra de vidro impregnada com glicoldimetacrilato (Fibrante ${ }^{\circledR}$ ) como, a concentração de sílica, a composição da matriz resinosa que envolve a sílica e o tipo de silano utilizado na superfície das fibras, não são disponibilizadas pelos fabricantes e, provavelmente, são segredos industriais. Esse fato dificulta a comparação dos resultados deste trabalho com os demais existentes na literatura. 
As fibras de poli(aramida), ao contrário das fibras de vidro que são compostas basicamente de óxido de sílica, têm por base um polímero orgânico, denominado comercialmente de $\operatorname{Kevlar}^{\circledR}\left(\right.$ DuPont $\left.^{\circledR}\right)$. Essas fibras são originadas quimicamente da família dos nylons e apresentam aplicações industriais diversas: na construção de embarcações, como polímero estrutural, por possuírem uma alta resistência mecânica com uma densidade muito baixa; na indústria aeronáutica por sua alta tenacidade à fadiga, alta resistência ao fogo e rigidez estrutural; na indústria bélica por sua alta resistência à tração, alta resistência química, alta resistência ao corte, propriedades requeridas à fabricação de laminados à prova de bala. Essas características apresentadas pelas fibras $\mathrm{Kevlar}^{\circledR}$, associadas à alta resistência à tração e alto módulo de elasticidade (rigidez) tornaram-na um material bem visto em Odontologia, como possível reforço das resinas odontológicas.

Os resultados obtidos, por meio da análise estatística, mostraram os seguintes valores para a resistência à fratura: para o grupo não reforçado as médias foram $275,27 \mathrm{~N} ; 81,14 \mathrm{~N} ; 62,71 \mathrm{~N}$ correspondentes aos comprimentos de 7, 14 e $21 \mathrm{~mm}$ respectivamente; para o grupo reforçado com fibra Kevlar $^{\circledR}$ as médias foram 312,69N; 89,97N; 50,64N correspondentes aos comprimentos de 7,14 e $21 \mathrm{~mm}$; para o grupo reforçado com fibra Fibrante ${ }^{\circledR}$, nos comprimentos antes mencionados, as médias foram 302,98N; 91,25N; $67,29 \mathrm{~N}$, respectivamente.

As fibras de vidro têm sido associadas ao aumento da resistência à fratura de espécimes de resina PMMA. Alguns autores como Bastos; 
Ferreira $^{2}$, Hamza et al. ${ }^{18}$, John; Gangadahar e $\mathrm{Shah}^{23}$, Keyf, Uzun e Mutlü ${ }^{24}$, Kim e Watts $^{25}$, Vallittu ${ }^{49}$, Miettinen, Vallittu ${ }^{29}$, Narva et al. $^{30}$, Vallittu ${ }^{47}$, Vallittu ${ }^{48}$, Vallittu ${ }^{49}$, Vallittu $^{53}$, Vallittu; Lassila; Lappalainen ${ }^{55}$, Stipho ${ }^{42}$, encontraram em seus trabalhos um aumento significativo da resistência flexional em relação a espécimes em resina PMMA não reforçados. Resultados, da mesma forma discrepantes, foram encontrados sobre o efeito das fibras de poli(aramida) (Kevlar ${ }^{\circledR}$ ) sobre as propriedades mecânicas de resinas PMMA. Vallittu ${ }^{47}$, Vallittu; Lassila; Lappalainen ${ }^{55}$, John; Gangadahar; Shah ${ }^{23}$ relataram um aumento relevante da resistência flexional de espécimes em PMMA reforçados com fibras de poli(aramida).

Ao contrário destes trabalhos que apresentaram resultados favoráveis quando utilizaram fibras de vidro e fibras de poli(aramida) com o intuito de aumentar a resistência à fratura, nosso trabalho evidenciou que em relação ao tipo de reforço utilizado, não houve diferença estatisticamente significante entre os espécimes reforçados e os não reforçados, apresentando-se valores semelhantes entre si. Esses resultados são semelhantes aos encontrados por Uzun; Hersek; Tinçer $(1999)^{45} ;$ Hazelton $(1995)^{20}$ e Samadzadeh $(1997)^{38}$.

Algumas variáveis relacionadas ao material e métodos desses estudos podem justificar as diferenças entre os seus resultados. Por exemplo, diversos autores defendem que quanto maior a união entre as fibras de vidro e a resina, maior a resistência flexional dos espécimes ${ }^{14,45,47,54,55}$. O silano tem sido descrito como o material que promove essa união efetiva entre o PMMA e a fibra de vidro $47,50,54,55,56$. Justificando a sua importância, há pelo menos um estudo que compara dois compostos de silano aplicados sobre uma fibra de vidro e 
o seu efeito sobre a resistência flexional de uma resina PMMA ${ }^{47}$. Assim, para alguns autores, fibras de vidro não silanizadas parecem não exercer qualquer influência na resistência de polímeros de $\mathrm{PMMA}^{21,47,54}$.

A forma como as fibras de vidro ou de poli(aramida) são tratadas imediatamente antes de sua inclusão no interior do espécime de PMMA é, igualmente, uma variável relevante. A imersão dessas fibras em monômero MMA é vista, por alguns autores, como causa da presença de bolhas de ar na interface fibra-resina, decorrentes da maior contração de polimerização do monômero MMA (21\%) em relação ao polímero PMMA (7\%). Associa-se essa diferença na contração de polimerização a um menor aumento da resistência flexional e, por isso, propõe-se a adição de uma mistura fluida de PMMA-MMA, preferencialmente, à imersão da fibra em monômero $\mathrm{MMA}^{55}$. Outros estudos mostram, entretanto, que o aumento da quantidade de monômero líquido MMA ao redor das fibras, antes de sua incorporação à mistura final da resina PMMA, parece contribuir para o melhor molhamento das fibras e menor incorporação de bolhas de $\operatorname{ar}^{49,56}$. Vallittu $(1998)^{56}$, além disso, observou que o uso de uma mistura fluida de PMMA-MMA não resulta em uma impregnação ótima das fibras pela resina PMMA. Escolhemos, por isso, imergir ambos os reforços utilizados em nosso trabalho, em monômero MMA, pois vários estudos relatam que esse método melhora a união entre reforços de qualquer natureza e a resina $13,38,49,50,51,60$.

A localização das fibras no interior do espécime é de suma importância. Um corpo de prova em forma de prótese provisória sobre implante com extensão em cantilever, sendo submetido a um teste compressivo de resistência à 
fratura, no extremo distal do cantilever, sofre deformação de tração na superfície oclusal das áreas dos conectores. Seguindo esta teoria, neste trabalho, a melhor localização para se inserir as fibras seria o mais superiormente possível nas áreas de conexão, na região onde se desenvolvem as forças de tração ${ }^{32,34,51,52 .}$

A carga máxima suportada, suportada em $\mathrm{N}$, diz respeito à resistência à fratura do espécime. Quando o comprimento do cantilever foi de $7 \mathrm{~mm}$ todos os grupos, reforçados ou não, apresentaram valores médios de resistência à fratura significativamente maiores que os demonstrados pelos grupos com 14 e 21 $\mathrm{mm}$ de comprimento. Analisando cada grupo em separado, quando se aumentou o comprimento do cantilever, diminuiu-se de forma significante o valor médio da carga máxima suportada.

Muitas sugestões têm sido feitas na literatura em relação ao comprimento do cantilever, mas em geral os vários autores concordam que, de acordo com a qualidade óssea, considera-se aceitável entre 10 a $20 \mathrm{~mm}$ de extensão ${ }^{35,39,57,36}$. Isto corresponde aproximadamente à distância mésio-distal de um pré-molar e um molar. Talvez um dos achados mais convincentes deste e de outros estudos $^{39,59}$ é o fato de que o aumento do cantilever tem um efeito marcante sobre a concentração de tensões e a resistência a fratura. Quanto mais longo o cantilever, maior tensão é observada. Desde o ponto de vista clínico, existem outros fatores como: a força oclusal a ser exercida, a dentição oposta, natural ou restaurada, bem como o biotipo do paciente e sinais de parafunção; que devem ser considerados e que influenciam no comprimento do cantilever ${ }^{35}$.

As próteses parciais fixas incluindo aquelas simuladas no presente estudo apresentam os conectores, ou seja, as regiões que unem os 
retentores ao pôntico ou que unem pônticos entre si, como as áreas mais finas dessa estrutura representando o elo frágil desse sistema. Durante um ensaio de resistência à fratura, uma tensão compressiva é gerada sobre a região do pôntico onde esta sendo aplicada a força. Esta região, entretanto, é pouco afetada, em decorrência da presença de uma combinação favorável entre as "propriedades do material" e a "área de distribuição de força". Entendemos como "propriedades do material" a capacidade, neste caso, da resina acrílica PMMA autopolimerizável responder mecanicamente de maneira propícia às tensões de compressão não se fraturando como um material friável, nem se deformando como um material borrachóide. Associada a esta característica, temos a "área de distribuição de força" que corresponde no presente trabalho à área de contato entre a superfície oclusal e esfera de aço de $\varnothing$ 8,0 mm que esta imprimindo a força. Esta área de contato foi conseguida pelo ajuste do provisório à referida esfera ainda no enceramento, auxiliando na melhor distribuição das forças durante o ensaio.

As regiões dos conectores apresentam-se como elo frágil mecânico do sistema em função de suas dimensões reduzidas em ambos os sentidos vestíbulo-lingual e cérvico-oclusal quando comparados como o restante da prótese. Estas regiões são mais delgadas, pois de maneira importante correspondem às áreas de alívios importantes e relacionam-se com o alojamento adequado da papila gengival interdental e ameias vestibular e lingual.

A manutenção da saúde dos tecidos gengivais que margeiam os pilares protéticos, incluindo a papila gengival, além da fibromucosa localizada adjacente aos pônticos é de suma importância para a conservação dos tecidos de suporte e perpetuação de qualquer tratamento reabilitador como próteses 
parciais fixas. Qualquer reação inflamatória desses tecidos pode gerar situações clínicas inconvenientes imensuráveis e irreversíveis ao sistema biológico relacionado à prótese: quadros clínicos de hiperplasia gengival, evolução da doença pelo acumulo de placa microbiana, reabsorção da crista óssea, perda de inserção, desconforto, dor, sangramento, e nos casos de próteses sobre implantes, pode gerar perimplantite que pode causar a perda do próprio implante. A manutenção do equilíbrio desse sistema é fornecida em parte pela preservação dos tecidos periodontais de suporte e proteção, através de superfícies polidas da restauração e do seu desenho que permita um fácil acesso à higienização pelo paciente, e pelo adequado arranjo oclusal que permita uma tolerância às forças tanto pelo material envolvido na confecção de prótese quanto pelo periodonto de suporte ${ }^{10}$. Desta maneira, qualquer um destes fatores mecânicos ou biológicos não deve ser negligenciado.

A capacidade dos reforços estudados em conter a propagação da trinca é que vai ditar o modo de fratura de espécime em resina. A trinca, uma vez gerada, ao se propagar no interior do espécime em sentido diagonal no pôntico e encontrar o reforço em uma direção perpendicular, pode levar a uma falha na interface adesiva entre as fibras e a resina que pode ser estabilizada (Fratura Parcial) ou continuar até a fratura total do provisório, porém, sem fraturar o reforço que permanecendo íntegro mantêm as duas partes fraturadas da resina unidas (Fratura Total Não Separada). Se a adesão entre as fibras e a resina, entretanto, for maior que a resistência coesiva da fibra, isto pode levar a fratura completa da fibra (Fratura Total Separada). Esta resistência à propagação de fratura 
pode ser atribuída a uma real união química ou a retenção mecânica da fibra à resina, ou ainda, a ambos. ${ }^{17,21}$

Em relação ao modo de fratura todos os espécimes do Grupo Controle, nos três comprimentos de cantilever avaliados, exibiram uma fratura de $100 \%$ do tipo Total Separada, com separação completa dos provisórios em duas partes, evidenciando a incapacidade da resina PMMA, de dissipar as tensões induzidas sobre ela quando submetida à uma carga que tende a flexioná-la ${ }^{2}$.

Os grupos Kevlar e Fibrante, por sua vez, sofreram uma ocorrência de $100 \%$ de fraturas de tipo Parcial, nos três comprimentos de cantilever estudados, mostrando a eficiência do reforço em conter a propagação de trinca, evitando uma fratura com completa separação do provisório.

Estes resultados estão de acordo com o estudo de Samadzadeh $(1997)^{38}$, em que, submetendo próteses parciais fixas confeccionadas com PMMA reforçadas com uma fibra de poli(etileno) à uma carga axial não observou fraturas totais com separação da prótese em dois segmentos, ao contrario, as conexões permaneceram intactas e somente uma porção do pôntico foi perdida em função da falha coesiva do PMMA.

Resultados similares ao nosso trabalho foram os descritos por Hazelton et al. $(1995)^{20}$, por sua vez, descreveram que não encontraram nenhuma diferença significativa na resistência à fratura entre as próteses com e sem reforço, entretanto, os autores relataram que os reforços mantiveram as duas peças fraturadas contíguas. Da mesma maneira Bastos, Ferreira², em 2003, encontraram 
que as fraturas dos espécimes reforçados foram consideradas mais favoráveis, ocorrendo de forma predominante os tipos Ausente e Parcial.

Em condições clínicas, a ausência de fratura ou fratura parcial faz parte, certamente, de um comportamento ideal esperado, reduzindo o risco de perda, ingestão ou aspiração da prótese provisória, já as fraturas do tipo total separada acarretam em um maior tempo clinico na confecção de novas restaurações ${ }^{6,20,38,52}$.

Em nenhum dos grupos observou-se qualquer outra forma de falha, como exemplo, fratura na interface resina-componente protético, fratura na margem dos provisórios ou fratura dos parafusos protéticos.

A indicação de se utilizarem fibras com a intenção de reforçar as próteses fixas implanto-suportadas é defendida por diversos autores ${ }^{5,8,37}$. Os autores advogam que os benefícios do uso das próteses finais reforçadas com fibras de diversas naturezas vão além de uma relação custo-benefício mais favorável, em comparação às infra-estruturas metálicas fundidas, principalmente em ouro $^{5}, 8,9,37$. Discutem que as próteses reforçadas com fibras exibem também adequada rigidez e resistência mecânica ${ }^{4,5,8,9,37}$. Entretanto, são raros os trabalhos que propõem o reforço de próteses provisórias. Binon ${ }^{8}$ alerta que, em próteses provisórias com espaços protéticos longos ou que apresentem cantilever, é prudente realizar o reforço da mesma. O autor sugere o uso de uma fibra de poli(aramida) para este fim.

Compreende-se, por fim, que resistência à fratura adequada é apenas um dos requisitos das próteses provisórias implanto-suportadas, que 
devem nortear a escolha de um material ou técnica. A pesar das limitações dos testes laboratoriais quanto à reprodução de situações clínicas, os mesmos são úteis e necessários para a comparação de materiais e técnicas em situações controladas $^{19}$

Diante de nossos resultados, tanto a fibra Kevlar como Fibrante podem ser utilizadas como reforços em próteses provisórias sobre implantes com o intuito de evitar a situação mais desfavorável do tipo de fratura. A fibra de vidro Fibrante, por sua vez, apresenta algumas vantagens como a translucidez e a sua disponibilidade comercial no mercado nacional.

Por fim, constata-se que a utilização de ambas as fibras, somados a toda demonstração do seu beneficio por diversos autores torna a técnica da confecção de próteses provisória reforçadas com fibras um método simples e prático orientado ao sucesso clinico. 
7 CONCLUSÕES 


\section{CONCLUSÕES}

Segundo o método empregado e com base nos resultados obtidos nas condições laboratoriais deste estudo, pode-se concluir que:

a) Sobre a resistência a fratura:

a.1) Quando o comprimento do cantilever foi de $7 \mathrm{~mm}$ todos os grupos apresentaram valores médios de resistência à fratura significativamente maiores que os demonstrados pelos grupos com 14 e $21 \mathrm{~mm}$ de comprimento.

Analisando cada grupo em separado, quando se aumentou o comprimento do cantilever, diminuiu-se de forma significante o valor médio da carga máxima suportada.

a.2) Em relação ao tipo de reforço utilizado, os resultados exibiram que não houve diferença estatisticamente significante entre os espécimes reforçados e os não reforçados, apresentando-se valores semelhantes entre si.

b) Em relação ao modo de fratura:

Todos os espécimes do grupo controle, com os diferentes comprimentos do cantilever avaliados, exibiram 100\% de fraturas do tipo Total Separada. Os grupos Fibrante e Kevlar, por sua vez sofreram uma ocorrência de $100 \%$ de fraturas do tipo parcial. 
ANEXOS 
ANEXO 1 - Quadro demonstrativo dos valores de resistência à fratura (em Kgf e em N) e modo de fratura dos espécimes do Grupo Controle - $7 \mathrm{~mm}$ de comprimento do cantilever

\begin{tabular}{|c|c|c|c|}
\hline Espécimes & Carga (Kgf) & Carga (N) & Modo de fratura \\
\hline 1 & 30,500 & 299,11 & Total separada \\
\hline 2 & 32,000 & 313,82 & Total separada \\
\hline 3 & 22,000 & 215,75 & Total separada \\
\hline 4 & 22,500 & 220,65 & Total separada \\
\hline 5 & 26,750 & 262,33 & Total separada \\
\hline 6 & 32,450 & 318,23 & Total separada \\
\hline 7 & 21,750 & 213,30 & Total separada \\
\hline 8 & 37,500 & 367,76 & Total separada \\
\hline 9 & 23,750 & 232,91 & Total separada \\
\hline 10 & 31,500 & 308,92 & Total separada \\
\hline Média & 28,07 & 275,27 & \\
\hline
\end{tabular}


ANEXO 2 - Quadro demonstrativo dos valores de resistência à fratura (em Kgf e em N) e modo de fratura dos espécimes do Grupo Controle - $14 \mathrm{~mm}$ de comprimento do cantilever

\begin{tabular}{|c|c|c|c|}
\hline Espécimes & Carga (Kgf) & Carga (N) & Modo de fratura \\
\hline 1 & 6,350 & 62,27 & Total separada \\
\hline 2 & 8,450 & 82,86 & Total separada \\
\hline 3 & 8,700 & 85,32 & Total separada \\
\hline 4 & 7,150 & 70,12 & Total separada \\
\hline 5 & 8,750 & 85,81 & Total separada \\
\hline 6 & 10,100 & 99,05 & Total separada \\
\hline 7 & 10,300 & 101,01 & Total separada \\
\hline 8 & 6,850 & 67,17 & Total separada \\
\hline 9 & 10,800 & 105,91 & Total separada \\
\hline 10 & 5,300 & 51,97 & Total separada \\
\hline Média & 8,27 & 81,14 & \\
\hline
\end{tabular}


ANEXO 3 - Quadro demonstrativo dos valores de resistência à fratura (em Kgf e em N) e modo de fratura dos espécimes do Grupo Controle - $21 \mathrm{~mm}$ de comprimento do cantilever

\begin{tabular}{|c|c|c|c|}
\hline Espécimes & Carga (Kgf) & Carga (N) & Modo de fratura \\
\hline 1 & 8,250 & 80,90 & Total separada \\
\hline 2 & 5,850 & 57,37 & Total separada \\
\hline 3 & 5,200 & 50,99 & Total separada \\
\hline 4 & 5,550 & 54,42 & Total separada \\
\hline 5 & 5,500 & 53,93 & Total separada \\
\hline 6 & 6,500 & 63,74 & Total separada \\
\hline 7 & 6,600 & 64,72 & Total separada \\
\hline 8 & 6,550 & 64,23 & Total separada \\
\hline 9 & 7,650 & 75,02 & 61,78 \\
\hline 10 & 6,300 & 62,71 & \\
\hline Média & 6,39 & & \\
\hline
\end{tabular}


ANEXO 4 - Quadro demonstrativo dos valores de resistência à fratura (em Kgf e em N) e modo de fratura dos espécimes do Grupo Kevlar ${ }^{\circledR}-7 \mathrm{~mm}$ de comprimento do cantilever

\begin{tabular}{|c|c|c|c|}
\hline Espécimes & Carga (Kgf) & Carga (N) & Modo de fratura \\
\hline 1 & 28,400 & 278,51 & Parcial \\
\hline 2 & 33,300 & 326,57 & Parcial \\
\hline 3 & 36,050 & 353,54 & Parcial \\
\hline 4 & 30,150 & 295,68 & Parcial \\
\hline 5 & 28,600 & 280,48 & Parcial \\
\hline 6 & 35,200 & 345,20 & Parcial \\
\hline 7 & 33,950 & 332,94 & Parcial \\
\hline 8 & 27,400 & 268,71 & Parcial \\
\hline 9 & 33,150 & 325,10 & Parcial \\
\hline 10 & 32,650 & 320,19 & \\
\hline Média & 31,89 & 312,69 & \\
\hline
\end{tabular}


ANEXO 5 - Quadro demonstrativo dos valores de resistência à fratura (em Kgf e em N) e modo de fratura dos espécimes do Grupo Kevlar ${ }^{\circledR}-14$ mm de comprimento do cantilever

\begin{tabular}{|c|c|c|c|}
\hline Espécimes & Carga (Kgf) & Carga (N) & Modo de fratura \\
\hline 1 & 13,250 & 129,94 & Parcial \\
\hline 2 & 6,250 & 61,29 & Parcial \\
\hline 3 & 9,200 & 90,22 & Parcial \\
\hline 4 & 10,500 & 102,97 & Parcial \\
\hline 5 & 9,300 & 91,20 & Parcial \\
\hline 6 & 10,400 & 101,99 & Parcial \\
\hline 7 & 8,600 & 84,34 & Parcial \\
\hline 8 & 6,450 & 63,25 & Parcial \\
\hline 9 & 8,450 & 82,86 & \\
\hline 10 & 9,350 & 91,69 & 89,97 \\
\hline Média & 9,18 & & \\
\hline
\end{tabular}


ANEXO 6 - Quadro demonstrativo dos valores de resistência à fratura (em Kgf e em N) e modo de fratura dos espécimes do Grupo Kevlar ${ }^{\circledR}-21 \mathrm{~mm}$ de comprimento do cantilever

\begin{tabular}{|c|c|c|c|}
\hline Espécimes & Carga (Kgf) & Carga (N) & Modo de fratura \\
\hline 1 & 4,050 & 39,71 & Parcial \\
\hline 2 & 4,550 & 44,62 & Parcial \\
\hline 3 & 4,850 & 47,56 & Parcial \\
\hline 4 & 5,600 & 54,91 & Parcial \\
\hline 5 & 5,350 & 52,46 & Parcial \\
\hline 6 & 6,300 & 61,78 & Parcial \\
\hline 7 & 4,600 & 45,11 & Parcial \\
\hline 8 & 6,250 & 61,29 & Parcial \\
\hline 9 & 5,150 & 50,50 & Parcial \\
\hline 10 & 4,950 & 48,54 & \\
\hline Média & 5,16 & 50,64 & \\
\hline
\end{tabular}


ANEXO 7 - Quadro demonstrativo dos valores de resistência à fratura (em Kgf e em N) e modo de fratura dos espécimes do Grupo Fibrante ${ }^{\circledR}-7$ mm de comprimento do cantilever

\begin{tabular}{|c|c|c|c|}
\hline Espécimes & Carga (Kgf) & Carga (N) & Modo de fratura \\
\hline 1 & 31,700 & 310,88 & Parcial \\
\hline 2 & 35,700 & 350,10 & Parcial \\
\hline 3 & 32,550 & 319,21 & Parcial \\
\hline 4 & 25,200 & 247,13 & Parcial \\
\hline 5 & 36,150 & 354,52 & Parcial \\
\hline 6 & 33,750 & 330,98 & Parcial \\
\hline 7 & 31,800 & 311,86 & Parcial \\
\hline 8 & 32,400 & 317,74 & Parcial \\
\hline 9 & 22,900 & 224,58 & Parcial \\
\hline 10 & 26,800 & 262,82 & Parcial \\
\hline Média & 30,90 & 302,98 & \\
\hline
\end{tabular}


Anexo 8 - Quadro demonstrativo dos valores de resistência à fratura (em Kgf e em N) e modo de fratura dos espécimes do Grupo Fibrante ${ }^{\circledR}-14$ mm de comprimento do cantilever

\begin{tabular}{|c|c|c|c|}
\hline Espécimes & Carga (Kgf) & Carga (N) & Modo de fratura \\
\hline 1 & 7,600 & 74,53 & Parcial \\
\hline 2 & 10,650 & 104,44 & Parcial \\
\hline 3 & 9,175 & 89,97 & Parcial \\
\hline 4 & 13,975 & 137,05 & Parcial \\
\hline 5 & 8,575 & 84,09 & Parcial \\
\hline 6 & 12,325 & 120,87 & Parcial \\
\hline 7 & 9,425 & 92,43 & Parcial \\
\hline 8 & 7,875 & 77,23 & Parcial \\
\hline 9 & 5,125 & 50,26 & Parcial \\
\hline 10 & 8,325 & 81,64 & \\
\hline Média & 9,31 & 91,25 & \\
\hline
\end{tabular}


ANEXO 9 - Quadro demonstrativo dos valores de resistência à fratura (em Kgf e em N) e modo de fratura dos espécimes do Grupo Fibrante ${ }^{\circledR}-21$ mm de comprimento do cantilever

\begin{tabular}{|c|c|c|c|}
\hline Espécimes & Carga (Kgf) & Carga (N) & Modo de fratura \\
\hline 1 & 9,650 & 94,63 & Parcial \\
\hline 2 & 7,500 & 73,55 & Parcial \\
\hline 3 & 7,525 & 73,79 & Parcial \\
\hline 4 & 7,650 & 75,02 & Parcial \\
\hline 5 & 3,725 & 36,53 & Parcial \\
\hline 6 & 6,975 & 68,40 & Parcial \\
\hline 7 & 7,550 & 74,04 & Parcial \\
\hline 8 & 4,500 & 44,13 & Parcial \\
\hline 9 & 8,200 & 80,41 & \\
\hline 10 & 5,350 & 52,46 & 67,29 \\
\hline Média & 6,86 & & \\
\hline
\end{tabular}


REFERÊNCIAS BIBLIOGRÁFICAS 


\section{REFERÊNCIAS BIBLIOGRÁFICAS}

1. Bae JM, Kim KN, Hattori M, Hasegawa K, Yoshinari M, Kawada E, et al. The flexural properties of fiber-reinforced composite with light-polymerized polymer matrix. Int J Prosthodont. 2001;14:33-9.

2. Bastos, LGC. Avaliação da resistência flexional, do módulo de elasticidade e do tipo de fratura de uma resina acrílica para restaurações provisórias - efeito de diversos reforços. [Dissertação] Bauru: Faculdade de Odontologia de Bauru, Universidade de São Paulo; 2003.

3. Batista, J. Provisórias: características ideais. [Texto na internet] [acesso disponível em: http://www.odontogeral.hpg.ig.com.br/provisorias.html

4. Behr M, Rosentritt M, Lang R, Handel G. Glass fiber-reinforced abutments for dental implants. A pilot study. Clin Oral Impl Res. 2001;12:174-8.

5. Bergendahl T, Ekstrand K, Ruyter IE. Evaluation of implant supported carbon/graphite fiber reinforced poly (methyl methacrylate) prostheses. Clin Oral Implan Res. 1995;6:246. 
6. Berrong JM, Weed RM, Young JM. Fracture resistance of Kevlar-reinforced poly(methyl methacrylate) resin: a preliminary study. Int J Prosthodont. 1990;3:391-5.

7. Bidez MW, Misch CE. Force transfer in implant dentistry: basic concepts and principles. J Oral Implantol. 1992;18:264-74.

8. Binon $P$, Sullivan D. Provisional fixed restorations technique for osseointegrated implants. J Calif Dent Ass. 1990;18:23-30.

9. Björk N, Ekstrand K, Ruyter IE. Implant-fixed, dental bridges from carbon/graphite fibre reinforced poly (methyl methacrylate). Biomaterials. 1986;7:73.

10. Burns DR, Beck DA, Nelson SK. A review of selected dental literature on contemporary provisional fixed prosthodontic treatment: report of the committee on research in fixed prosthodontics of the academy of fixed prosthodontics. J Prosthet Dent. 2003;90:474-97.

11. Carroll CE, Von Fraunhofer JA. Wire reinforcement of acrylic resin prostheses. J Prosthet Dent. 1984;52:639-41.

12. Dinato JC, Polido WD. Restaurações Unitárias Planejamento e Execução. In: A. Medicas. Implantes Osseointegrados Cirurgia e Prótese. São Paulo. Brasil, 2001;138-65. 
13. Dixon DL, Breeding LC. The transverse strengths of three denture base resins reinforced with polyethylene fibers. J. Prosthet Dent. 1992;67:417-19.

14. Ekstrand K, Ruyter E, Wellendorf H. Carbon/graphite fiber reinforced poly(methylmethacrylate): properties under dry and wet conditions. J Biomed Mater Res. $1987 ; 21: 1065-80$.

15. Frederick D. Provisional/transitional implant-retained fixed restorations. J Calif Dent Assoc. 1995;23:19-26.

16. Freilich MA, Duncan JP, Alarcon EK, Eckrote KA, Goldberg AJ. The design and fabrication of fiber-reinforced implant protheses. J Prosthet Dent. 2002;88:44954.

17. Grant AA, Greener EH. Whisker reinforcement of polymethyl methacrylate denture base resins. Aust Dent J. 1967;12:29-33.

18. Hamza TA, Rosenstiel SF, Elhosary MM, Ibraheem R. The effect of fiber reinforcement on the fracture toughness and flexural strength of provisional restorative resins. J Prosthet Dent. 2004;91:258-64.

19. Hazelton DR, Diaz-Arnold AM, Vargas MA. Flexural strength of provisional crown and fixed partial denture resins. J Prosthet Dent. 2002;87:225-8. 
20. Hazelton LR, Nicholls JI, Brudvik JS, Daly $\mathrm{CH}$. Influence of reinforcement design on the loss of marginal fixed partial dentures. Int $\mathbf{J}$ Prosthodont. 1995;8:572-9.

21. Henry PJ, Bishop BM, Purt RM. Fiber-reinforced plastics for interim restorations. Quintessence Dent Technol Yearbook. 1990-1991:110-23.

22. Jaques L. Análise do estresse gerado em componentes de prótese fixa implanto-suportada, através do uso de extensômetros. [Dissertação] Bauru: Faculdade de Odontologia de Bauru, Universidade de São Paulo; 2000.

23. John J, Gangadhar SA, Shah I. Flexural strength of heat-polymerized polymethyl methacrylate denture resin reinforced with glass, aramid, or nylon fibers. J Prosthet Dent. 2001;86:424-7.

24. Keyf F, Uzun G, Mutlu M. The effects of HEMA- monomer and air atmosphere treatment of glass fibre on the transverse strength of a provisional fixed partial denture resin. J Oral Rehabil. 2003;30:1142-8.

25. Kim SH, Watts DC. Effect of glass-fiber reinforcedment and water storage on fracture toughness (Kjc) of polymer-based provisional crown and FPD materials. Int J Prosthodont. 2004;17:318-22. 
26. Koumjian Jh, Nimmo A. Evaluation of fracture resistance of resins used for provisional restorations. J Prosthet Dent. 1990;64:654-7.

27. Larson WR, Dixon DL, Aquilino SA, Clancy JMS. The effect of carbon graphite fiber reinforced on the strength of provisional crown and fixed partial denture resins. J Prosthet Dent. 1991;66:816-20.

28. Lastumäki TM, Lassila LVJ, Vallittu PK. Flexural properties of the bulk fiberreinforced composite DC-tell used in fixed partial dentures. Int $\mathbf{J}$ Prosthodont. $2001 ; 4: 22-6$.

29. Miettinen VM, Vallittu PK. Release of residual methyl methacrylate into water from glass fibre-poly(methyl methacrylate) composite used in dentures. Biomaterials 1997;18:181-5.

30. Narva KK, Lassila LV, Vallittu PK. The static strength and modulus of fiber reinforced denture base polymer. Dent Mat. 2005;21:421-8.

31. Nevins M, Skurow HM. The intracrevicular restorative margin. Int J Periodontics Restorative Dent. 1984;4:30-49.

32. Nohrström TJ, Vallittu PK, Yli-Urpo A. The effect of placement and quantity of glass fibers on the fracture resistance on interim fixed partial dentures. Int $\mathbf{J}$ Prosthodont. 2000;13:72-8. 
33. Pegoraro L F. Prótese fixa. 1.ed. São Paulo: Artes Medicas: Série EAPAPCD. 2000;7:111-48.

34. Powell DG, Nicholls JI, Youdelis RA, Strygler H. A comparison of wire- and Kevlar-reinforced provisional restorations. Int J Prosthodont. 1994;7:81-9.

35. Rangert B, Jemt T, Jörneus L. Forces and Moments on Branemark implants. Int J Oral Maxillofac Implants 1989;4:241-7.

36. Rubo JH. Análise das tensões em prótese sobre implantes pelo método de elemento finito: estudo paramétrico de sete variáveis clínicas. [Tese Livre Docência] Bauru: Faculdade de Odontologia de Bauru, Universidade de São Paulo; 2004.

37. Ruyter IE, Ekstrand K, Björk N. Development of carbon/graphite fiber reinforced poly (methyl methacrylate) suitable for implant-fixed dental bridges. Dent Mat. 1986;2:6-9.

38. Samadzadeh A, Kugel G, Hurley E, Aboushala A. Fracture strengths of provisional restorations reinforced with plasma-treated woven polyethylene fiber. J Prosthet Dent. 1997;78:447-50. 
39. Sertgöz A, Güvener S. Finite element analysis of the effect of cantilever and implant length on stress distribution in an implant-supported fixed prosthesis. $\mathbf{J}$ Prosthet Dent. 1996;76:165-9.

40. Shackleton J, Carr L, Slabbert JCG, Lownie JF. Prosthodontic complication and problems of fixture-supported prostheses. J Dent Res. 1992;71:1113.

41. Skalak R. Biomechanical considerations in osseointegrated prostheses. J Prosthet Dent. 1983;49:843-8.

42. Stipho HD. Effect of glass fiber reinforcement on some mechanical properties of autopolymerizing polymethyl methacrylate. J Prosthet Dent. 1998;79:580-4.

43. Taner B, Dogan A, Tínçer T, Akinay AE. A study on impact and tensile strength of acrylic resin filled with short ultra-high molecular weight polyethylene fibers. J Oral Sci 1999;41:15-8.

44. Todescan F, Bottino MA. Aplicações Clínicas dos Implantes Osseointegrados. In: A. Medicas. Atualização na clínica odontológica. São Paulo. Brasil,1996.

45. Uzun G, Hersek N, Tinçer T. Effect of five woven fiber reinforcements on the impact and transverse strength of a denture base resin. $\mathbf{J}$ Prosthet Dent. 1999;81:616-20. 
46. Uzun G, Keyf F. The effect of fiber reinforcement type and water storage on strength properties of a provisional fixed partial denture resin. $\mathbf{J}$ Biomater Applications. 2003;17:277-86.

47. Vallittu PK. Comparison of two different silane compounds used for improving adhesion between fibres and acrylic denture base material. J. Oral Rehabil. 1993;20:533-9.

48. Vallittu PK. Acrylic resin-fiber composite - part II: the effect of polymerization shrinkage of polymethyl methacylate applied to fiber roving on transverse strength. $\mathbf{J}$ Prosthet Dent. 1994;71:613-7.

49. Vallittu PK. The effect of void space and polymerization time on transverse strength of acrylic-glass fibre composite. J Oral Rehabil. 1995;22:257-61.

50. Vallittu PK. Glass fiber reinforced in repaired acrylic resin removable dentures: preliminary results of a clinical study. Quintessence Int. 1997;28:39-44.

51. Vallittu PK. Ultra-high-modulus polyethylene ribbon as reinforcement for denture polymethyl methacrylate: a short communication. Dent Mater. 1997;13:3812.

52. Vallittu PK. The effect of glass fiber reinforcement on the fracture resistance of a provisional fixed partial denture. J Prosthet Dent. 1998;79:125-30. 
53. Vallittu PK. Flexural properties of acrylic resin polymers reinforced with unidirectional and woven glass fibers. J Prosthet Dent. 1999;81:318-26.

54. Vallittu PK, Lassila VP. Reinforcement of acrylic resin denture base material with metal or fibre strengtheners. J Oral Rehabil. 1992;19:225-30.

55. Vallittu PK, Lassila VP, Lappalainen R. Acrylic resin-fiber composite - part I: the effect of fiber concentration on fracture resistance. $\mathbf{J}$ Prosthet Dent. $1994 ; 71: 607-12$.

56. Vallittu PK, Ruyter IE, Ekstrand K. Effect of water storage on the flexural properties of e-glass and silica fiber acrylic resin composite. Int $\mathbf{J}$ Prosthodont. 1998;11:340-50.

57. Van Zyl PP, Grundling, Jooste, Terblanche. Three-Dimensional finite element model of a human mandible incorporating six osseointegrated implants for stress analysis of mandibular cantilever prostheses. Int $\mathbf{J}$ Oral Maxillofac Implants $1995 ; 10: 51-7$

58. Wang RL, Moore BK, Goodacre CJ, Swartz ML, Andres CJ. A comparison of resin for fabricating provisional fixed restorations. Int J Prosthodont 1989;2:173-84.

59. White SN, Caputo AA, Anderqvist T. Effect of cantilever length on stress transfer by implant-supported prostheses. J Prosthet Dent. 1994;71:493-9. 
60. Yazdanie N, Mahood M. Carbon fiber acrylic resin composite: an investigation of transverse strength. J Prosthet Dent. 1985;54:543-7. 
ABSTRACT 


\begin{abstract}
Evaluation of the resistance to the fracture of temporary fixed prostheses implant-supported varying the extension of the cantilever and the fiber type: glass fibers and poliaramid fibers.
\end{abstract}

In the oral rehabilitator treatment, the provisory restorations have extremely importance. The resistance and durability of materials used in the execution are critical, especially in extended treatments and in vast toothless spaces. The goal of this work was to demonstrate the resistance and the types of fracture of specimens that simulate a fixed prosthesis of three elements changing the extension of cantilever $(7,14 \mathrm{e} 21 \mathrm{~mm})$, made of acrylic resin polymethylmethacrylate (PMMA) autopolymer, with and without reinforcement in its interior, built over implant components. The reinforcements used were: fiberglass (Fibrante ${ }^{\circledR}$ - Angelus ${ }^{\circledR}$, Londrina, PR, Brazil) and poliaramid fiber (Kevlar ${ }^{\circledR}$ - Du Pont ${ }^{\circledR}$, USA). The groups have 10 specimens each, including a group of control, without reinforcement. The specimens were submitted to a compressor charge until its fracture. The analysis of results (ANOVA, $p<0,05$ ) for the test of resistance, showed that there is no statistic difference between the groups regarding the type of reinforcement; however, there is a significant statistic difference regarding the cantilever extension. When the extension of cantilever was $7 \mathrm{~mm}$, all groups showed medium values of resistance to fractures, in $\mathrm{N}$, significant more than the showed by the groups with 14 and $21 \mathrm{~mm}$ of extension. In relation with the types of fracture, the 
reinforcement groups show fractures more favorable to be repaired, even when they were partially fractured.

Keywords: Acrylic resins. Temporary dental restoration. Mechanical stress. 